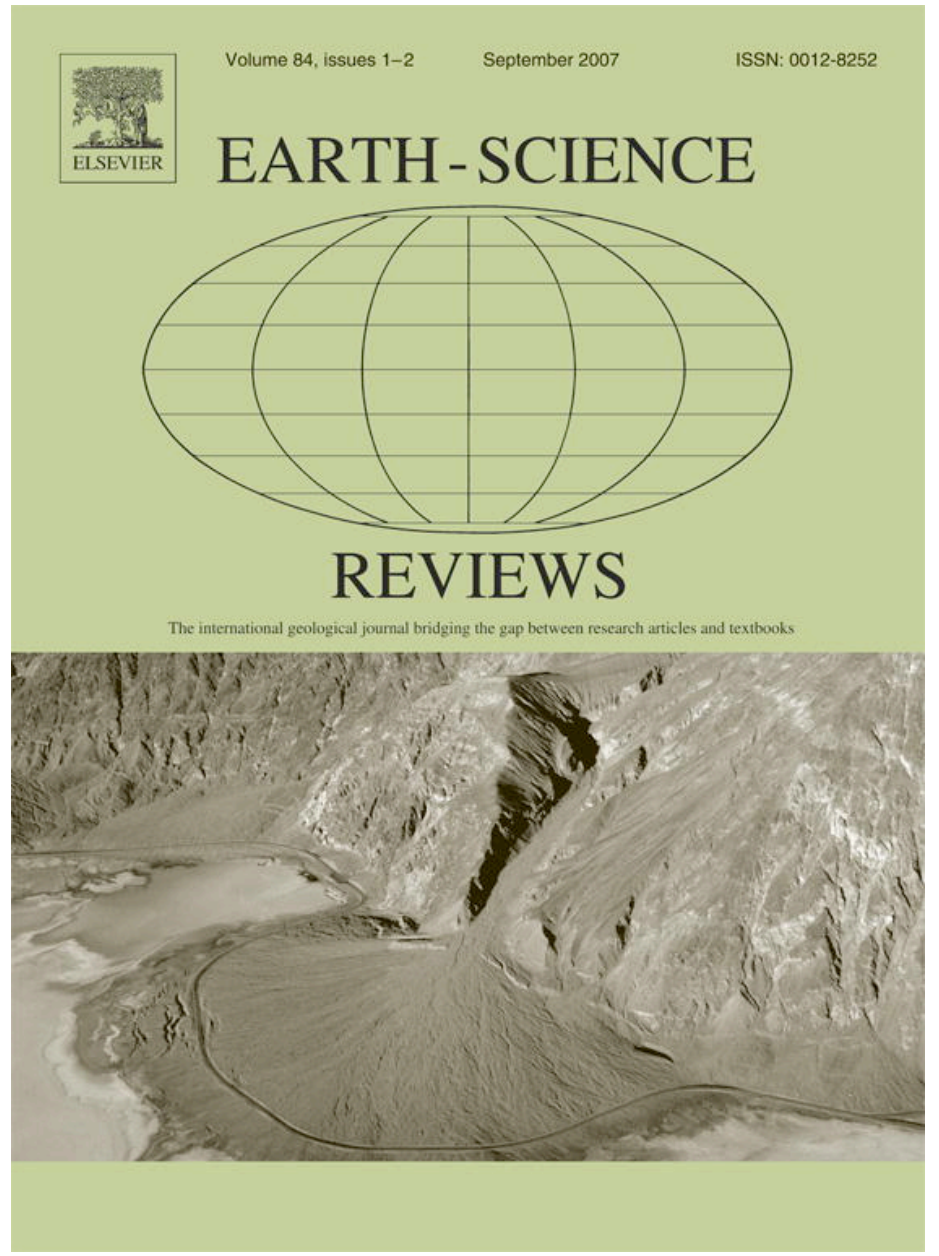




\title{
The nonmarine Triassic-Jurassic boundary in the Newark Supergroup of eastern North America
}

\author{
S.G. Lucas ${ }^{\mathrm{a}, *}$, L.H. Tanner ${ }^{\mathrm{b}}$ \\ ${ }^{a}$ New Mexico Museum of Natural History, 1801 Mountain Road N.W., Albuquerque, NM 87104, USA \\ b Department of Biological Sciences, Le Moyne College, 1418 Salt Springs Road, Syracuse, NY 13214, USA
}

Received 28 December 2006; accepted 9 May 2007

Available online 26 May 2007

\begin{abstract}
For the last three decades, the position of the Triassic-Jurassic boundary (TJB) in nonmarine strata has largely been based on its palynostratigraphic placement just below the oldest basalts of the Central Atlantic magmatic province (CAMP) in the Newark Supergroup of eastern North America. This boundary, however, is demonstrably older than the TJB as it is defined in marine strata. Thus, the palynostratigraphic change used to place this TJB in the Newark most resembles a late Norian change in the European section and does not correspond to any palynological event at the marine-defined TJB. Conchostracan biostratigraphy suggests that the TJB is in the Newark extrusive zone above the oldest CAMP basalt, and vertebrate biostratigraphy is consistent with this placement of the TJB. Radioisotopic ages indicate that the TJB defined in marine strata is no older than 200 MA, but the oldest CAMP basalts of the Newark Supergroup consistently yield ages averaging about 201 Ma. Magnetostratigraphic correlation of the Newark section to the TJB section at St. Audrie's Bay in England also indicates that the onset of CAMP volcanism in the Newark Supergroup is older than the marine TJB. Correlations based on carbon and osmium isotopes are also consistent with this correlation. Thus, all data indicate that the TJB in the Newark Supergroup is above the lowest CAMP basalt in the Newark extrusive zone. Correct placement of the TJB in the Newark Supergroup allows key nonmarine and marine events to be sequenced across the TJB, indicating the following succession of events: crurotarsan ("thecodont") extinction, the palynofloral turnover in the Newark, the first CAMP eruptions, the extinctions of Rhaetian ammonites and conodonts, and the first appearance of Jurassic psiloceratid ammonites.
\end{abstract}

(C) 2007 Elsevier B.V. All rights reserved.

Keywords: Triassic; Jurassic; Newark Supergroup; mass extinction

\section{Introduction}

The end of the Triassic (Triassic-Jurassic boundary: TJB) has long been identified as the time of one of the five largest mass extinctions in earth history. Recent challenges to this conclusion (Hallam, 2002; Tanner

\footnotetext{
* Corresponding author. Tel.: +1 5058412873 ; fax: +1 505841 2808.

E-mail address: spencer.lucas@state.nm.us (S.G. Lucas).
}

et al., 2004; Lucas and Tanner, 2004) argue that several extinctions took place during the Late Triassic that have been compounded by insufficient stratigraphic resolution/correlation to create the appearance of a single mass extinction. Stratigraphic resolution and correlation is thus critical to evaluating different ideas about the timing, severity and causation of the TJB extinctions.

A particularly important problem for the correlation of the TJB has been its placement in the nonmarine section. During the last three decades, placement of the TJB in the 
nonmarine Newark Supergroup strata of eastern North America (Figs. 1,2) has provided a datum to which other nonmarine sections have been correlated (e.g., Olsen and Galton, 1977; Fowell and Olsen, 1993; Lucas, 1998; Lucas and Huber, 2003; Marzoli et al., 2004). This datum, established primarily in the Newark basin of New Jersey, places the TJB in the uppermost Passaic Formation just below the oldest basalt sheet of the Central Atlantic magmatic province (CAMP), which in the Newark basin is the Orange Mountain Basalt (Figs. 1, 2). Establishment of a nonmarine datum for the TJB in the Newark Supergroup is of particular importance because the extensive study of cyclostratigraphy and magnetostratigraphy in the Newark makes it central to global correlation of the Late Triassic (e.g., Hounslow et al., 2004). Here, we challenge the accepted datum by arguing that this "nonmarine TJB" is demonstrably older than the TJB defined in the marine section. Indeed, all evidence indicates that the TJB in the Newark section is stratigraphically higher than (not below) the base of the CAMP basalts. This has significant bearing on the synchrony of events on land and in the sea across the TJB and for understanding the potential relationship between CAMP volcanism and the end-Triassic extinctions.

\section{Definition of the Triassic-Jurassic boundary}

The long-accepted definition of the TJB (base of Jurassic System = base of Hettangian Stage) has been the lowest occurrence of the smooth-shelled psiloceratid ammonite Psiloceras planorbis in southern England (Fig. 2) (e.g., Lloyd, 1964; Maubeuge, 1964; Cope et al., 1980; Warrington et al., 1994; Ogg, 2004a,b; Gradstein et al., 2004). However, current work under the guidelines of the IUGS International Commission on Stratigraphy seeks ratification of a GSSP (global stratotype section and point) for that boundary (Warrington, 2005). Criteria for possible boundary definition include a negative carbon isotope excursion, a bivalve bio-event, an evolutionary turnover in radiolarians, continued use of the lowest occurrence of $P$. planorbis, or the lowest occurrence of ammonites of the $P$. tilmanni group (Lucas et al., 2005) (Fig. 3).

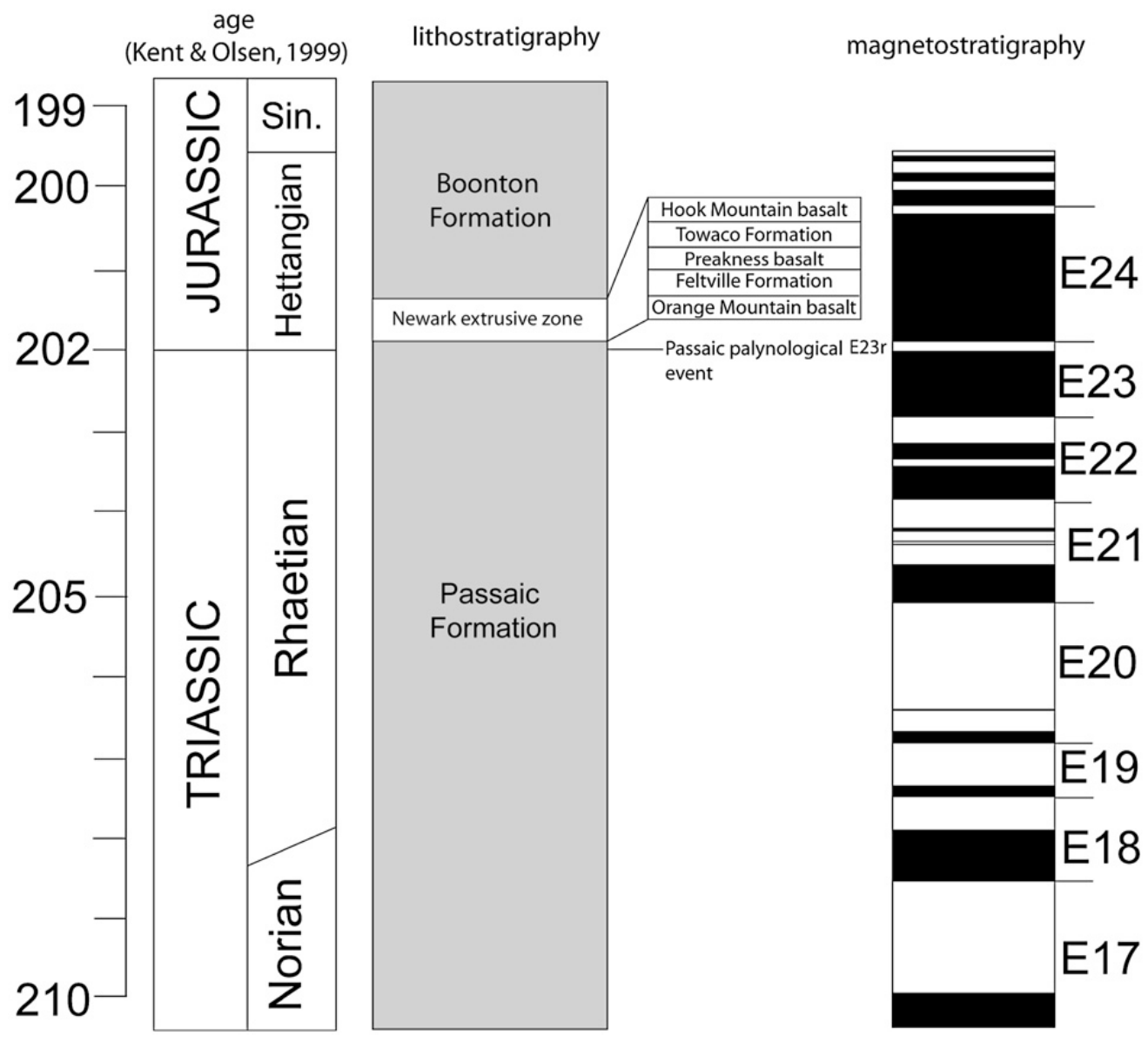

Fig. 1. Summary of lithostratigraphy and magnetostratigraphy of the Triassic-Jurassic boundary interval of the Newark Supergroup in the Newark basin of New Jersey-Pennsylvania, USA. Age assignments are from Kent and Olsen (1999). Note location of Passaic palynological event below oldest CAMP basalt sheet. 


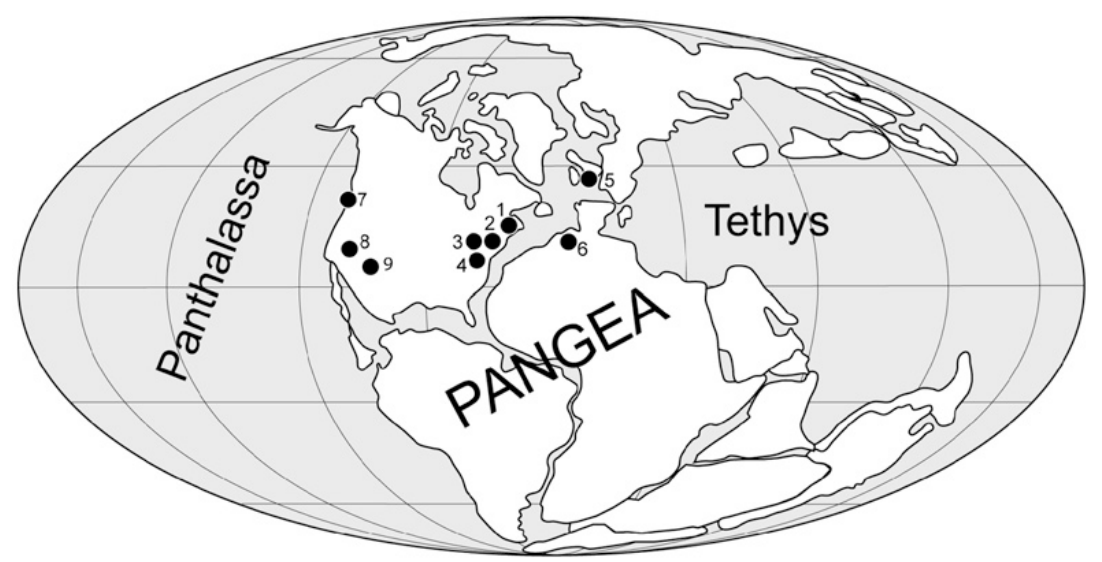

Fig. 2. Simplified map of Late Triassic Pangea showing locations of key Triassic-Jurassic boundary sections referred to in the text. $1=$ Fundy basin, Nova Scotia, Canada; 2 = Hartford basin, Connecticut, USA; 3 = Newark basin, New Jersey-Pennsylvania, USA; 4 = Culpeper basin, Virginia, USA; $5=$ St. Audrie's Bay, England; $6=$ Morocco, Central High Atlas and Argana basin; 7 = Queen Charlotte Islands, British Columbia, Canada; $8=$ New York Canyon area, Nevada, USA; 9 = Four Corners, USA.

It is essential to emphasize that: (1) the TJB is a datum defined in marine strata; (2) the accepted definition of the TJB remains the lowest occurrence of P. planorbis; we use this definition, although we favor a slightly older definition of the base of the Jurassic at the lowest occurrence of ammonoids of the Psiloceras tilmanni group (cf. Guex et al., 2004); and (3) placement of the TJB in the nonmarine section is achieved by correlating to the marine TJB. Thus there can be only one TJB, not separate TJBs for marine and for nonmarine strata. Also, we note that various authors have used different definitions of the Rhaetian, and in this article, to be consistent with the usage of most other work referred to herein, we use the same base of the Rhaetian as Gallet et al. (2007), which includes the latter part of Sevatian 2 ("long" Rhaetian).

\section{Biostratigraphy of the nonmarine TJB}

\subsection{Correlation to the marine boundary}

Four principal lines of evidence are available to correlate a point in the nonmarine section to the TJB defined in marine strata: (1) biostratigraphy (palynomorphs, conchostracans and vertebrates); (2) radioisotopic ages; (3) magnetostratigraphy; and (4) chemostratigraphy (carbon, osmium and strontium isotopes as well as iridium enrichment). Here, we review these data to attempt a correlation of the marine TJB to nonmarine strata, especially those of the Newark Supergroup.

\subsection{Palynostratigraphic constraints}

Until the 1970s, most paleontologists considered the entire Newark Supergroup section, including the
CAMP basalts (which, with intercalated sediments, are termed the Newark extrusive zone), to be of Triassic age (see historical review by Lorenz, 1988). The first serious challenge to such an age assignment came from palynology, which remains the primary means by which the position of the TJB is determined in the Newark Supergroup.

Cornet et al. (1973) and Cornet and Traverse (1975) presented palynological data from the Hartford basin of Connecticut (Fig. 2) to indicate that the strata between the CAMP basalts (especially the Shuttle Meadow

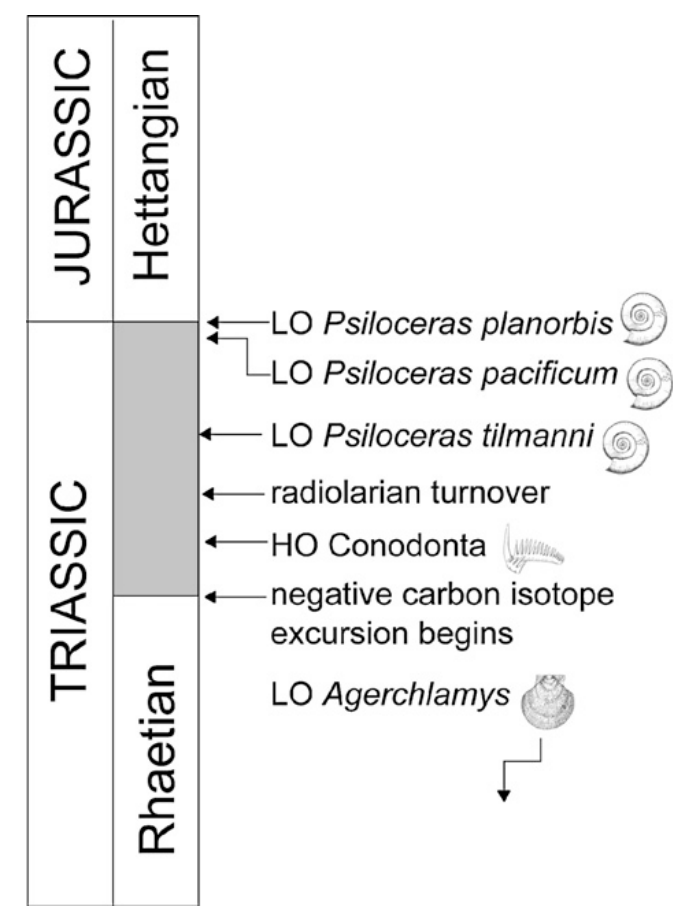

Fig. 3. Succession of potential marker events for definition of the Triassic-Jurassic boundary (after Lucas et al., 2005). HO = highest occurrence, $\mathrm{LO}=$ lowest occurrence. 
Formation) have a palynoflora that they described as "Rhaeto-Liassic," and the Portland Formation above the highest CAMP basalt has a Liassic palynoflora. Olsen and Galton (1977) cited Cornet's work and concluded that the palynological data indicate a Jurassic age for the Newark extrusive zone and overlying strata, and they assigned a "Rhaetic" age to the strata immediately beneath the basalts.

Cornet's (1977) unpublished doctoral dissertation established a palynostratigraphy for the Newark Supergroup. He thus defined and correlated three palynostratigraphic zones in the Newark that are relevant to placement of the TJB (Fig. 4): (1) lower Passaic-Heidlersburg palynoflora of supposed Norian age; (2) Manassas-upper Passaic (later renamed upper Balls Bluff-upper Passaic: Litwin et al., 1991) palynoflora of supposed Rhaetian age; and (3) Corollina meyeriana palynoflora of supposed Hettangian-early Sinemurian age.

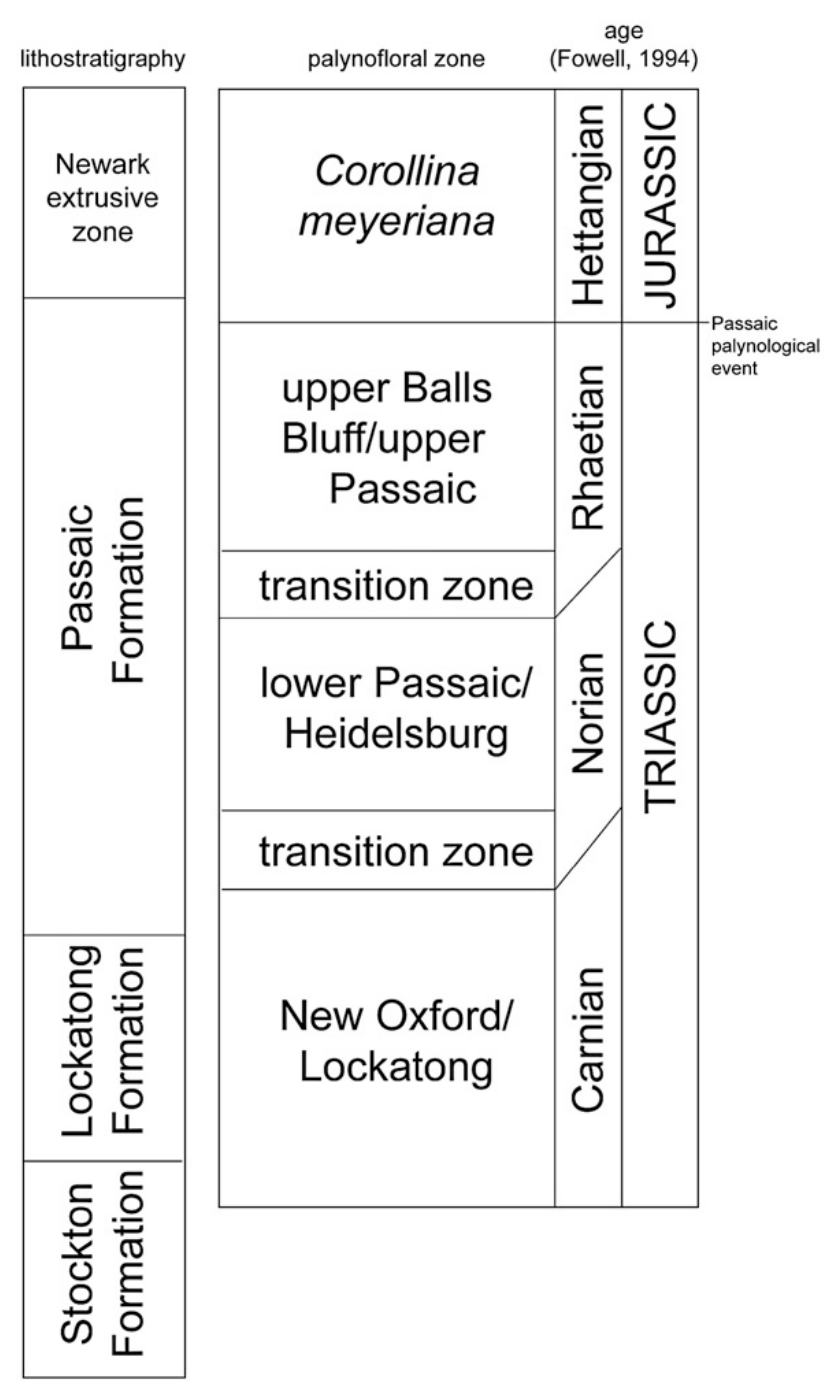

Fig. 4. Palynomorph zones of the Newark Supergroup and their correlation to the Triassic-Jurassic boundary (after Fowell, 1994).
Cornet and Olsen (1985) thus placed the TJB at the base of the C. meyeriana palynofloral zone of Cornet (1977), which is just below the CAMP basalts. The basis for this placement was "a switch from a high diversity assemblage dominated by bisaccate pollen, including Patinosporites, C. meyeriana, C. torosus, and Granuloperculatipollis rudis, to a low diversity assemblage very strongly dominated $(+90 \%)$ by the circumpolles C. meyeriana" (Cornet and Olsen, 1985, p. 72). They further stated that 'this transition takes place over an $80 \mathrm{~m}$ thick 'barren' interval below the Orange Mountain Basalt in the Newark basin (Jacksonwald syncline). By the top of this interval all taxa characteristic of the Late Triassic are absent." Furthermore, the "first common appearance" of Convolutispora klukiforma was also cited as evidence of the Jurassic age of the $C$. meyeriana palynofloral zone. In the Jacksonwald syncline of the Newark basin, Olsen et al. (2002b) place this boundary within $10 \mathrm{~m}$ to $15 \mathrm{~m}$ of the base of the Orange Mountain Basalt. In the Fundy basin, at Partridge Island, this transition is placed just $20 \mathrm{~cm}$ to $30 \mathrm{~cm}$ below the base of the North Mountain Basalt (Fowell and Traverse, 1995; Olsen et al., 2005).

However, not all palynologists accepted the correlation of the Newark palynostratigraphic zones to the marine timescale advocated by Cornet (1977) and Cornet and Olsen (1985). Thus, for example, Litwin et al. (1991) considered the lower Passaic Heidlersburg palynoflora to be of early Norian age, and they assigned a middle Norian age to the upper Balls Bluff-upper Passaic palynoflora. Litwin et al. made this age assignment because they considered the youngest palynological assemblage of the Chinle Group in the southwestern USA (their "zone III") to be of early Norian age, and the upper Balls Bluff-upper Passaic palynofloral zone to be younger than any palynomorph assemblage from the Chinle Group. However, we note that the zone III assemblage is from Chinle strata that, based on magnetostratigraphy and vertebrate biostratigraphy, range in age from early through late Norian (Lucas, 1998; Molina-Garza et al., 2003; Lucas and Tanner, 2007). Thus, we do not accept the early Norian age assigned to the zone III assemblage by Litwin et al. (1991).

Fowell (1994; Fowell et al., 1994; Fowell and Olsen, 1993, 1995; Fowell and Traverse, 1995) evaluated the TJB pollen records in the Newark, Culpeper and Fundy basins to arrive at the same conclusions as Cornet with regard to placement of the TJB (Fig. 4). Nevertheless, Fowell noted that "the Newark Supergroup assemblages lack characteristic Rhaetian palynomorphs found in European type sections" and that "abundance peaks of Corollina appear to be time-transgressive in Europe" (Fowell, 1994, p. 5). Despite this, Fowell (1994) relied 
on the highest occurrences of three palynomorph species (G. rudis, Patinasporites densus and Enzonalasporites vigens), which she perceived as late Rhaetian in Europe, to assign a Rhaetian age to the upper Balls Bluff-upper Passaic pollen assemblage. In so doing, she discounted the highest occurrence of Vallasporites in the European section (of Norian age according to Fowell) and the fact that the species $G$. rudis, $P$. densus and $E$. vigens have Norian records in Europe. Indeed, on face value, the taxa Fowell used to assign a Rhaetian age to the upper Balls Bluff-upper Passaic palynoflora are indicative of a Norian age (cf. Fowell and Olsen, 1995, Fig. 1).

Gradstein et al. (1994) and Van Veen (1995) critiqued the palynostratigraphic criteria used to place the TJB in the Newark Supergroup. These authors pointed out that in Western Europe the virtual disappearance of many vesicate palynomorphs characteristic of the Triassic takes place during the late Norian (e.g., Warrington, 1974; Mostler et al., 1978; Morbey, 1978; Schuurman, 1979). Thus, this event in the Newark section can most reasonably be identified as a late Norian event, not the TJB. Fowell and Olsen (1995) have attempted to counter these arguments by suggesting that Late Triassic floral provinciality, controlled largely by paleolatitudinal differences, accounts for discrepancies in the timing of turnover between the Newark and the Tethyan realm. This argument is refuted by updated paleogeographic reconstructions of the positions of this regions based on the most recent paleomagnetic data (Kent and Tauxe, 2005).

Hounslow et al. (2004) compared the palynomorph record across the TJB in the St. Audrie's Bay section of England (Fig. 2) to that of the Newark Supergroup, noting that the St. Audries Bay section shares the following taxa with the upper Balls Bluff-upper Passaic palynofloral zone: G. rudis, Alisporites thomasii, Tsugaepollenites pseudomasulae, Carnisporites spinigeri, C. leviornatus and Porcellispora longdonensis. However, at St. Audrie's Bay these taxa, except for $C$. leviornatus (which is restricted to the upper Penarth Group), all have their abundance peaks in strata of the Mercia Mudstone Group (mostly Blue Anchor Formation) generally assigned a Norian age. They are rare in the overlying Penarth Group, and only A. thomasii is found stratigraphically higher, in the Lias Group. Thus, species-level taxa of palynomorphs shared between the St. Audrie's Bay section and the upper Balls Bluff-upper Passaic palynofloral zone support assigning a Norian age to the Newark palynofloral zone. Despite this, Hounslow et al. (2004) suggested that the pollen record of the upper Penarth Group - an increasing diversity of miospores followed by a circumpolles-dominated assemblage - is similar to and possibly correlative with the pollen change in the Newark at the top of the upper Balls Bluff-upper Passaic palynofloral zone (also see Whiteside et al., 2007).

Nevertheless, in the Newark Supergroup, the dominance of the palynoflora by $C$. meyeriana just below and including the NEZ does not necessarily indicate an earliest Jurassic age. This is because: (1) C. meyeriana has a stratigraphic range of Carnian-Early Jurassic; and (2) its acme (dominance) takes place at different times in different sections. Thus, for example, in the basal Liassic Planorbis beds of southern England, Corollina is the dominant constituent, although it also has a high abundance in some older beds (Warrington et al., 1995); in the North Sea basin it dominates lower Rhaetian assemblages (Lund, 1977); in Spain it has multiple abundance peaks in Rhaetian-Hettangian strata (Gómez et al., 2007); and in Austrian sections it has both Rhaetian and Norian peaks (Morbey and Neves, 1974; Morbey, 1975; Kuerschner et al., 2007). Corollina (=Classopollis) is the pollen of cheirolepidaceous conifers that had an affinity for warm, moist coastal or upland environments (Hughes, 1976; Traverse, 1988b). The dominance of Corollina pollen in some Upper Triassic and Lower Jurassic strata correlates with marine transgression or with other changes to a wetter environment such as might have been associated with CAMP volcanism. Therefore, the sudden dominance of the Newark palynoflora by C. meyeriana may be interpreted as a result of regional climate change caused by uplift or volcanism, not as a biostratigraphic datum.

Cornet (1977) used taxa such as Corollina torosa to define the base of the Rhaetian in the Newark Supergroup, though it appears in the European section much earlier. Indeed, typical Rhaetian taxa are missing from the supposed Rhaetian interval of the Newark Supergroup, and those that are present have a NorianRhaetian age range. Thus, any correlation of the upper Balls Bluff-upper Passaic palynofloral zone to the European palynomorph record based on shared specieslevel taxa indicates a Norian age.

In the Newark Supergroup there is a striking change in the palynoflora below the lowest CAMP basalt. This change has either been equated to the TJB or, most recently, referred to as the " $\mathrm{T}-\mathrm{J}$ palynofloral turnover" (Whiteside et al., 2004). We instead refer to this change as the "Passaic palynofloral event" and suggest that it does not equate to the TJB and that it should no longer be considered an extinction event/turnover associated with the TJB. As Kozur and Weems (2005, p. 33) well observed, "there are no age-diagnostic sporomorphs or other fossils to prove that this extinction event occurred at the Triassic-Jurassic boundary." Indeed, an extensive 
literature documents the lack of a major extinction/ turnover of the terrestrial macroflora and microflora at the TJB (e.g., Orbell, 1973; Schuurman, 1979; Pedersen and Lund, 1980; Fisher and Dunay, 1981; Brugman, 1983; Niklas et al., 1983; Knoll, 1984; Ash, 1986; Traverse, 1988a; Edwards, 1993; Cleal, 1993a, b; Kelber, 1998; Hallam, 2002; Tanner et al., 2004; Lucas and Tanner, 2004; Kuerschner et al., 2007; Ruckwied et al., 2006).

Recently, Kuerschner et al. (2007) documented in great detail the transitional nature of the change in palynomorphs in the Kössen and Kendelbach formations in the Tiefengraben section (northern Calcareous Alps). They describe a Rhaetipollis-Limbosporites zone, correlative with the C. marshi ammonite zone, in which Corollina (both torosa and meyeriana) is abundant. The overlying Rhaetipollis-Porcellispora zone, in which $R$. germanicus disappears near the top, contains a Corollina peak, but also contains Triassic foraminifera. The succeeding TrachysporitesPorcellispora zone marks a decline in Corollina and the disappearance of Ovalipollis pseudolatus. The overlying Trachysporites-Heliosporites zone is characterized by the maximum abundance of $H$. reissingeri. These authors suggest that the Triassic-Jurassic boundary in this section can be placed within the TrachysporitesPorcellispora zone, which corresponds to Schuurman's (1977, 1979) Phase 4, or between it and the TrachysporitesHeliosporites zone, which corresponds to Phase 5 of Schuurman $(1977,1979)$. The authors further conclude that the Newark Passaic palynofloral event most likely represents an older, probably early Rhaetian event.

Paleobotanists have long identified a "Rhaeto-Liassic" megaflora (e.g., Barnard, 1973), largely because they are unable to distinguish distinct Rhaetian and early Liassic paleofloras. And, there is also a typical RhaetoLiassic microflora "dominated by bisaccate pollen grains, trilete spores and circumpolles" (Ruckwied et al., 2006). An exception to prevailing thought is McElwain et al. (1999), who claimed a significant macrofloral extinction at the TJB in East Greenland, although previously, Harris (1937) and Pedersen and Lund (1980) interpreted the same data as indicating species range truncations at a depositional hiatus. Alternatively, the floral turnover in East Greenland could be genuine, but nothing more than a local event, as no similar event is documented elsewhere (Hallam and Wignall, 1997; Tanner et al., 2004).

The question remains, is the change in the palynoflora that occurs in the Newark Supergroup just below

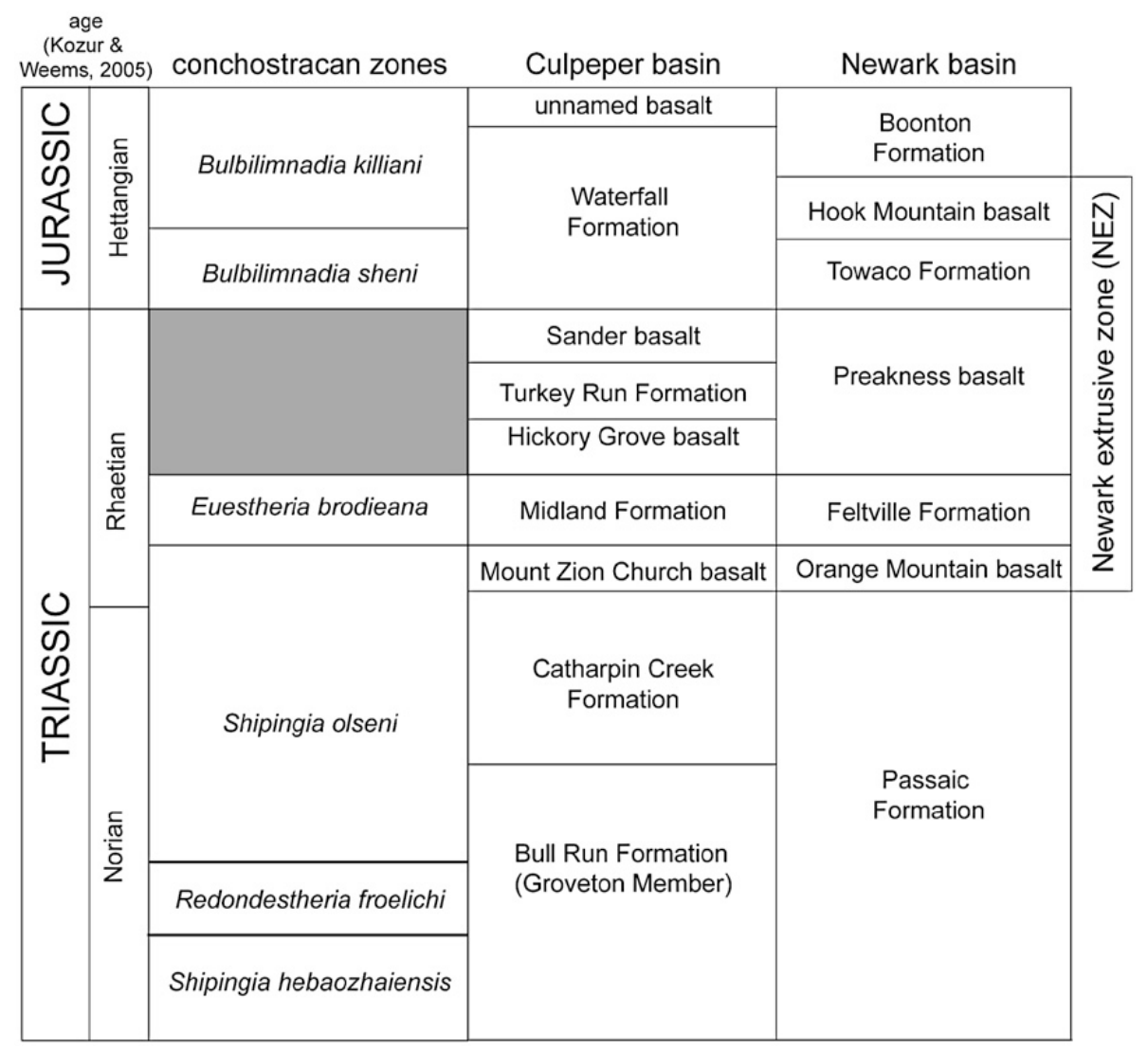

Fig. 5. Conchostracan zones of the Newark Supergroup and their correlation to the Triassic-Jurassic boundary (after Kozur and Weems, 2005). 
the CAMP basalts correlative with the TJB? It clearly does not correspond to any palynological event that takes place at the marine TJB. Indeed, if it corresponds to any palynological event in the Late Triassic, it is a late Norian or Rhaetian event (disappearance/diminution of many vessicate taxa). Thus, the best correlation that can be suggested only on the basis of palynostratigraphy is to conclude that the Passaic palynofloral event is of late Norian or Rhaetian age, not the TJB.

\subsection{Conchostracan biostratigraphy}

Nonmarine biostratigraphic correlations based on charophytes, ostracodes and conchostracans are common in Mesozoic strata, but only a detailed conchostracan biostratigraphy has been presented for the TJB interval (Kozur and Weems, 2005). This work documented the conchostracan record of the Newark Supergroup in the Culpeper and Newark basins (Fig. 2) to conclude that the base of the Jurassic is above the lowest CAMP basalt.

Kozur and Weems (2005) thus established a succession of conchostracan zones in the Newark section (Fig. 5) and correlated this conchostracan succession to Upper Triassic strata of the Chinle Group in the southwestern USA and the German Keuper and to Jurassic strata in China. Thus, conchostracans of their Shipingia zones and Redondaestheria zone are found in Upper Triassic (Norian) strata of the Chinle Group (Redonda Formation) and German section (Stubensandstein 3), whereas the lowest occurrence of Bulbilimnadia is a Jurassic event in the Chinese section (Chang et al., 1976; Chen and Shen, 1985). For this reason, Kozur and Weems (2005) placed the base of the Jurassic at the base of their Bulbilimnadia sheni zone at the approximate base of the Towaco Formation (Newark basin) and the Waterfall Formation (Culpeper basin), which places the TJB within the Newark extrusive zone (Fig. 5).

While we welcome the application of conchostracan biostratigraphy to the placement of the TJB in the Newark Supergroup, the work of Kozur and Weems (2005) is not without caveats. The conchostracan taxonomy impresses us as oversplit and therefore in need of sweeping taxonomic revisions (Lucas and Kirkland, 1998; Lucas and Milner, 2006). Furthermore, no standard biostratigraphic succession of conchostracans across the TJB exists outside of the Newark succession described by Kozur and Weems (2005). This forced Kozur and Weems (2005) to compare the Newark conchostracan succession to temporally and geographically scattered records in the Upper Triassic strata of the western USA and Germany and the Lower Jurassic strata of China. A more convincing correlation of their Newark conchostracan succession would be achieved if other, independentlycorrelated conchostracan records across the TJB were available. Thus, while the correlation of Kozur and Weems (2005) does support the conclusion that the TJB in the Newark Supergroup is above the lowest CAMP basalt sheet, it clearly merits further testing.

\subsection{Vertebrate biostratigraphic constraints}

Nonmarine (freshwater) fishes provide no biostratigraphic data useful to correlation of the TJB in nonmarine strata. Though there appear to be some changes in the freshwater fish fauna cross the TJB in the American Southwest (Huber et al., 1993a; Milner et al., 2006) and in the Newark Supergroup (Olsen et al., 1982), these are not synchronous changes between the two regions nor can they be directly correlated to the marine TJB. Therefore, vertebrate biostratigraphy across the TJB relies on tetrapod (amphibian and amniote) body fossils and footprints (Fig. 6).

Nevertheless, the use of tetrapods to place the TJB in nonmarine strata is compromised by the inability to correlate directly and precisely the fossil vertebrate record to any of the marine records that have been used to define the TJB. Furthermore, most vertebrate fossil assemblages "close" in age to the TJB are actually removed from that boundary by a few million years (Lucas, 1994). Most of the youngest Late Triassic vertebrate assemblages are in strata of Norian (Revueltian) age (Lucas, 1997, 1998, 1999), whereas most Early Jurassic vertebrate assemblages are of Sinemurian (Dawan) or younger age (Lucas, 1994, 1996, 2006). Relatively few vertebrate fossil assemblages are of Rhaetian or Hettangian age.

Lucas and Tanner (2007) recently discussed correlation of tetrapod assemblages across the TJB to the marine timescale. They noted that such correlations are based largely on magnetostratigraphy and palynostratigraphy and rare occurrences of nonmarine tetrapod fossils in marine strata. However, as Lucas and Tanner (2007, p. 10) noted, placement of the TJB and nearby marine stage boundaries with respect to the nonmarine tetrapod record remains "somewhat imprecise and uncertain." These correlations indicate that in the Newark Supergroup the Cliftonian tetrapod body fossils that occur below the lowest CAMP basalt are of Late Triassic age, though there is no vertebrate biostratigraphic basis for deciding whether they are Norian or Rhaetian (Fig. 6). The tetrapod assemblage from the McCoy Brook Formation in the Fundy Basin of Nova Scotia, above the lowest (and only) CAMP basalt in that basin (the North Mountain Basalt) appears to be of Early Jurassic, probably Hettangian age (Fig. 6). Tetrapod 


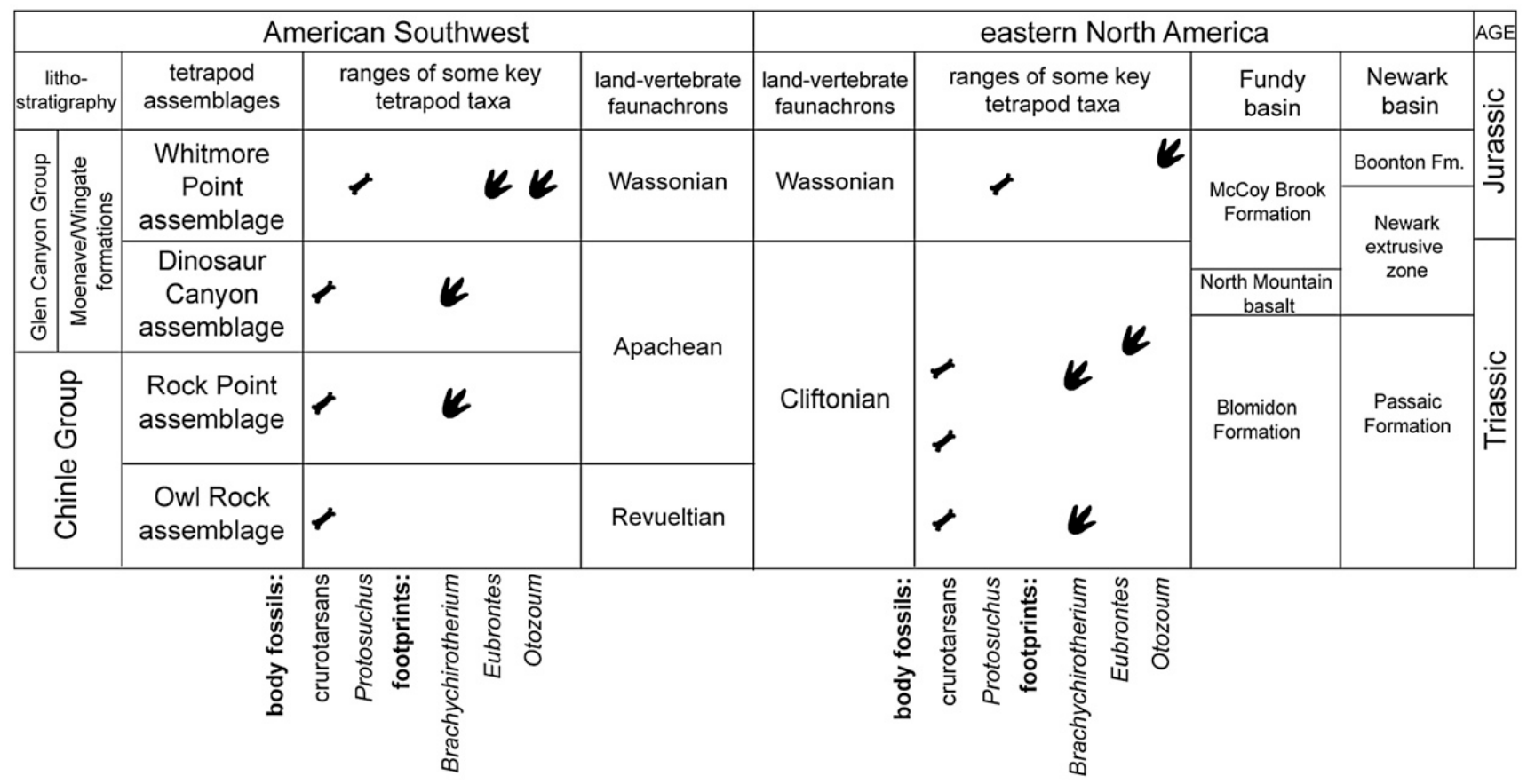

Fig. 6. Vertebrate biostratigraphic correlation across the Triassic-Jurassic boundary between the Four Corners, USA, section (Chinle and Glen Canyon groups) and the Newark Supergroup. Based, in part, on Lucas and Tanner (2006).

fossils from strata above the Newark extrusive zone in the Hartford basin also appear to be of Early Jurassic age. Vertebrate biostratigraphy thus appears to suggest that the base of the Jurassic is in the Newark extrusive zone (Fig. 6).

The idea of a substantial nonmarine tetrapod (amphibian and reptile) extinction at the end of the Triassic began with Colbert $(1949,1958)$, and has been more recently advocated by Olsen et al. (1987, 1990, 2002a,b), largely based on the tetrapod fossil record of the Newark Supergroup (eastern North America). Weems (1992), Benton (1994), Lucas (1994), Tanner et al. (2004) and Lucas and Tanner (2004) rejected this conclusion, arguing against building a case for extinction on the very incomplete vertebrate fossil record of the Newark Supergroup. Indeed, Huber et al. (1993b) plotted the stratigraphic ranges of all Triassic tetrapod taxa known from the Newark Supergroup, and only three body-fossil taxa (indeterminate phytosaurs, the procolophonid Hypsognathus and the sphenodontid Sigmala) actually are found in the youngest Triassic strata immediately below the Passaic palynofloral event. The last decade of collecting has not changed that, and only a few, fragmentary tetrapod fossils are known from the Newark extrusive zone and are not age diagnostic (Lucas and Huber, 2003). The McCoy Brook Formation in Nova Scotia yields a tetrapod assemblage generally considered Early Jurassic in age by vertebrate paleontologists (Olsen et al., 1987; Shubin et al., 1994; Lucas, 1998; Lucas and Huber, 2003; Lucas and Tanner, 2007), though it could straddle the marinedefined TJB. The Newark body fossil record of tetrapods is thus sparse across the TJB and therefore inadequate to evaluate a possible TJB tetrapod extinction, and the direct correlation of such an extinction (if it exists) to the marine TJB has not been demonstrated (Lucas and Tanner, 2007). Indeed, the most substantial extinction of tetrapods across the TJB is the crurotarsan extinction, which occurs well below the lowest CAMP basalt in the Newark Supergroup. This is the extinction of phytosaurs, aetosaurs and rauisuchians ("thecodonts") that has long represented the bulk of the supposed terminal Triassic tetrapod extinction.

Because the Newark Supergroup body fossil record of tetrapods is inadequate to demonstrate a mass extinction of tetrapods at the TJB, the tetrapod footprint record in the Newark Supergroup has been used instead (e.g., Olsen and Sues, 1986; Szajna and Silvestri, 1996; Olsen et al., 2002a,b). However, detailed stratigraphic study of the Newark footprint record indicates the disappearance of only four ichnogenera and the appearance of only two ichnogenera at the Passaic palynofloral event, with four ichnogenera continuing through this boundary; this does not qualify as a sudden mass extinction.

Part of the footprint change close to the Passaic palynofloral event is the lowest occurrence of the theropod footprint ichnogenus Eubrontes (as defined by Olsen et al., 1998, i.e., tridactyl theropod pes tracks longer than $28 \mathrm{~cm}$ ). The idea that the lowest occurrence 
of Eubrontes is the base of the Jurassic began with Olsen and Galton (1984), who advocated this datum because of the close correspondence between the lowest occurrence of Eubrontes in the Newark Supergroup and the Passaic palynofloral event. Thus, use of the lowest occurrence of Eubrontes to indicate the base of the Jurassic depends entirely on the palynostratigraphy, not on the stratigraphic distribution of the footprints themselves. Indeed, previously, Haubold (1971), in his global review of footprint ichnotaxa, considered Eubrontes to be both Late Triassic and Early Jurassic in age.

Subsequent to the correlations advocated by Olsen and Galton (1984), vertebrate ichnologists considered most Eubrontes tracks to be of Jurassic age but they did not equate the lowest occurrence of Eubrontes with the TJB (e.g., Haubold, 1986; Lockley and Hunt, 1994). These authors knew that most Eubrontes occurrences are in rocks generally considered Jurassic in age, though there was no way to correlate most of the occurrences to marine strata or, more importantly, they could not demonstrate a close coincidence of the lowest occurrence of Eubrontes and the TJB defined in marine strata.

Olsen et al. (2002a,b) further argued that the sudden appearance of Eubrontes, made by a Dilophosauruslike theropod, in the "earliest Jurassic" strata of the Newark Supergroup (just above the Passaic palynofloral event), indicates a dramatic size increase in theropod dinosaurs at the TJB. They interpreted this as the result of a rapid (thousands of years) evolutionary response by the theropod survivors of a mass extinction and referred to it as "ecological release" (Olsen et al., 2002a, p. 1307). They admitted, however, that this hypothesis can be invalidated by the description of Dilophosaurussized theropods or diagnostic Eubrontes tracks in verifiably Triassic-age strata.

Indeed, tracks of large theropod dinosaurs assigned to Eubrontes (or its synonym Kayentapus) are known from the Triassic of Australia, Africa (Lesotho), Europe (Great Britain, France, Germany, Poland-Slovakia, Scania) and eastern Greenland, invalidating the "ecological release" hypothesis (Lucas et al., 2006). A detailed review of these records indicates Carnian, Norian and Rhaetian occurrences of tracks that meet the definition of Eubrontes established by Olsen et al. (1998). Also, theropods large enough to have made at least some Eubrontes-size tracks are known from the Late Triassic body-fossil record and include Liliensternus from the Norian of Europe (estimated length of $\sim 5 \mathrm{~m}$ ) and Gojirosaurus from the Norian of the USA (estimated length $\sim 5.5 \mathrm{~m}$ ). Clearly, theropods that made Eubrontes-size tracks existed during the Late Triassic, and the sudden abundance of these tracks in the Newark Supergroup at the Passaic palynofloral event cannot be explained simply by rapid evolution of small theropods to large size following a mass extinction.

Thulborn (2003) argued that the Australian Triassic record of Eubrontes refutes the notion that its first occurrence is at the TJB. Olsen et al. (2003), nevertheless, claimed that the Australian Eubrontes tracks are actually tridactyl underprints of a pentadactyl chirothere track. However, the footprint of Eubrontes is mesaxonic (symmetrical around its long axis), as are the Australian Eubrontes tracks. Tridactyl underprints of chirotheres are paraxonic (asymmetrical around their long axis). Therefore, the Eubrontes tracks from the Upper Triassic of Australia are correctly identified. The concept of a sudden appearance of Eubrontes tracks due to "ecological release" at the TJB thus proposed by Olsen et al. $(2002 a, b)$ can be abandoned. Furthermore, tetrapod footprints do not provide a basis for precise placement of the TJB in the Newark Supergroup. Most Eubrontes tracks are Jurassic, but many are clearly Triassic (Lucas et al., 2006).

A few body fossil taxa of tetrapods and a few ichnogenera do seem to be restricted to either Triassic or Jurassic strata (Lucas and Tanner, 2007). Thus, no crurotarsan (aetosaur, phytosaur and rauisuchian) body fossil is demonstrably Jurassic, so the presence of crurotarsan fossils still can be relied on to indicate a Triassic age. Therefore, the stratigraphically highest crurotarsan tracks (usually referred to Brachychirotherium) are also apparently of Triassic age. The crocodylomorph Protosuchus is the stratigraphically lowest tetrapod body fossil in Jurassic strata and has not been demonstrated to occur in Triassic strata. The prosauropod track Otozoum is also apparently restricted to Jurassic strata (Rainforth, 2003), but given that Late Triassic prosauropod body fossils are known, this restriction may be more apparent than real.

The above appear to be the most reliable vertebrate biostratigraphic criteria for identifying the TriassicJurassic boundary in nonmarine strata, but they are criteria that have not been directly correlated to the marine definition of the TJB. Thus, the restriction of selected taxa to the Triassic or Jurassic is based on correlations rooted in magnetostratigraphy or palynostratigraphy, not on the co-occurrence of these taxa in marine strata or in strata that interfinger with or are otherwise unambiguously correlated to marine strata.

If the vertebrate fossil criteria listed here are applied to the Newark Supergroup, the highest occurrence of crurotarsan body fossils and the Brachychirotherium highest occurrence is below the lowest CAMP basalt sheet (Fig. 6). The lowest occurrence of Otozoum is 
above the Newark extrusive zone, and the lowest occurrence of Protosuchus is above the only CAMP basalt sheet present in the Fundy basin. This indicates that the TJB is between the highest occurrence of crurotarsans (below the oldest CAMP basalt) and the lowest occurrence of presumed Jurassic tetrapods, which is in and above the Newark extrusive zone. Vertebrate biostratigraphy thus suggests that the TJB is in the Newark extrusive zone.

\section{Radioisotopic constraints}

Although numerical age estimates of the TJB were mostly in the 180-200 Ma range before the 1970s (Menning, 1989), estimates of $200 \mathrm{Ma}$ or older became increasingly common subsequently. Palynostratigraphic placement of the TJB below the base of the CAMP basalts in the Newark Supergroup in the 1970s by Cornet (1977) then began to figure strongly in numerical age estimates of the TJB. Thus, numerical ages of 201-202 Ma for the Newark CAMP basalts became the primary basis for advocating $\mathrm{TJB}$ ages close to $200 \mathrm{Ma}$

In contrast, marine biostratigraphic placement of the TJB was long tied to older radioisotopic ages of about $208 \mathrm{Ma}$ (see Forster and Warrington, 1985 for a review). These ages, however, were based primarily on imprecisely dated plutons in British Columbia, Canada, that cut marine strata close in age to the TJB. Based primarily on the ages of these plutons, Forster and Warrington (1985) suggested an age of $205 \pm 5 \mathrm{Ma}$ for the TJB.

Pálfy et al. (2000) provided a direct numerical tiepoint for marine biostratigraphy across the TJB by publishing a $\mathrm{Pb} / \mathrm{U}$ age on an ash bed on Kunga Island in the Queen Charlotte Islands of British Columbia, Canada (Fig. 2). This age, 199.6 $\pm 0.3 \mathrm{Ma}$, is just below the stratigraphically highest conodont and several meters below the lowest occurrence of psiloceratid ammonites in that section. By current marine biostratigraphy, this is a latest Triassic age (late Rhaetian), and it indicates a TJB numerical age no older than $\sim 200 \mathrm{Ma}$. The age of 199.6 Ma has been used by the International Commission on Stratigraphy in its 2004 compilation as the best estimate of the age of the TJB (Ogg, 2004a,b; Gradstein et al., 2004).

Numerical age dating of the CAMP basalts of the Newark Supergroup has a long and complex history. Since 1990, most workers have applied the ages published by Dunning and Hodych (1990) on feeder intrusives of the CAMP basalts, which indicate they are $\sim 201-202 \mathrm{Ma}$. Recent Ar/Ar ages on the basalts in the Carolina piedmont place the oldest flow (Wachtung flow I) at 201.2 $\pm 2.1 \mathrm{Ma}$
(Hames et al., 2000). Indeed, Hames et al. (2000, p. 860), accepting the idea that the TJB is just below the CAMP basalts, suggested that this is a "direct, relatively precise determination of the age of the Triassic-Jurassic boundary." Recently, Schoene et al. (2006) reported a single crystal ${ }^{206} \mathrm{~Pb} /{ }^{238} \mathrm{U}$ age of $201.3 \pm 0.3 \mathrm{Ma}$ and a ${ }^{207} \mathrm{~Pb} /{ }^{235} \mathrm{U}$ age of $201.5 \pm 0.3 \mathrm{Ma}$ for the North Mountain basalt in the Fundy basin. These represent the most precise age determinations thus far for the CAMP basalts in the Newark basins.

Recently published ${ }^{40} \mathrm{Ar} /{ }^{39} \mathrm{Ar}$ ages of CAMP basalts in Morocco range from $200.3 \pm 2.6 \mathrm{Ma}$ for the lower flow unit to $199.8 \pm 1.8 \mathrm{Ma}$ for the upper flow unit (Marzoli et al., 2004; Knight et al., 2004). The weighted mean age for the lower unit is $200.1 \pm 0.6 \mathrm{Ma}$, whereas for the upper unit it is $199.4 \pm 1.1 \mathrm{Ma}$ (Knight et al., 2004). Note, though, that because of "systematic errors" in ${ }^{40} \mathrm{Ar} /{ }^{39} \mathrm{Ar}$ geochronology (e.g., Min et al., 2005; Schoene et al., 2006), these ${ }^{40} \mathrm{Ar} /{ }^{39} \mathrm{Ar}$ ages need to be adjusted by about $1 \%$ downward for comparison to $\mathrm{U} /$ $\mathrm{Pb}$ ages, so the data actually indicate ages close to $202 \mathrm{Ma}$. Or, viewed differently, the U/Pb ages indicate that the basal CAMP basalts of the Newark Supergroup are older than the TJB, whereas $\mathrm{Ar} / \mathrm{Ar}$ ages indicate a younger age for the Moroccan CAMP basalts (Nomade et al., 2007, Fig. 6).

In Morocco, palynomorphs immediately below the lower flow unit are mostly vesicate forms (including Patinasporites densus) that indicate a Late Triassic age. The simplest interpretation of these data is that the Moroccan CAMP basalts were extruded during the latest Triassic and rest directly on latest Triassic sediments. Indeed, if the sediments beneath the Newark CAMP basalts are of Triassic age, as we argue here, then there is no discrepancy between the Newark and Moroccan CAMP extrusions; they are coeval within biostratigraphic resolution and both rest on uppermost Triassic sediments.

Olsen and Kent (1999; also see Kent et al., 1995; Kent and Olsen, 1999), in their development of a Late Triassic magnetostratigraphy and astronomically-calibrated timescale, have mostly used $202 \mathrm{Ma}$ as the age of the TJB (Olsen et al., 1996 used $201 \mathrm{Ma}$ ), which they place at the Passaic palynofloral event a few meters below the base of the oldest CAMP basalt. Based on cyclostratigraphy, they argue that their palynostratigraphically-placed TJB (the Passaic palynofloral event) is only about 20-25 kyr older than the oldest basalt, and that the entire Newark extrusive zone encompasses no more than $600 \mathrm{kyr}$. If these numerical estimates are accepted, then the TJB $(\sim 200 \mathrm{Ma})$ must be younger than the Newark extrusive zone $(\sim 201-202 \mathrm{Ma})$. 
In his compilation of Triassic numerical ages, Ogg (2004a; also see Gradstein et al., 1994, 2004) indicated that the Newark Passaic palynofloral event is very close in age to the Norian-Rhaetian boundary. Therefore, his compilation placed the Norian-Rhaetian boundary at about 202-203 Ma, as he placed it stratigraphically just below the oldest CAMP basalt.

If the palynostratigraphically-placed TJB (Passaic palynofloral event of our terminology) in the Newark Supergroup has an age of 202 or $201 \mathrm{Ma}$, and the marine TJB is $\sim 200 \mathrm{Ma}$ or younger, then there is an obvious discrepancy of at least one million years between the two boundaries. Pálfy et al. (2000) recognized this (also see Ogg, 2004a,b), and by their estimation, the discrepancy is at least $700 \mathrm{kyr}$ if the maximum one sigma error ranges of the then available radioisotopic ages were used to calibrate their asynchrony. The important point here is that the radioisotopic ages indicate that there are two TJB boundaries: a marine TJB of $\sim 200 \mathrm{Ma}$ or slightly younger and the "Newark TJB" of $\sim 201-202 \mathrm{Ma}$ or slightly older.

However, the radioisotopic age story may not be as clear as just indicated. In an abstract, Pálfy and Mundil (2006) report ${ }^{206} \mathrm{~Pb} /{ }^{238} \mathrm{U}$ ages for an early Sinemurian horizon in Hungary of $198.0 \pm 0.6$ and a middle Hettangian horizon in Alaska of 200.6 $\pm 0.3 \mathrm{Ma}$. They suggest these ages indicate a TJB age older than $201 \mathrm{Ma}$, but until these new dates are fully published and the inaccuracy of the published age from Kunga Island is demonstrated (the other Hettangian-Sinemurian numerical ages published by Pálfy et al., 1999 must also be inaccurate), this is not certain. Indeed, a marine TJB age older than $201 \mathrm{Ma}$ creates problems not only for the palynostratigraphic correlations just advocated, but for magnetostratigraphic correlations by Hounslow et al. (2004) and Whiteside et al. (2007) discussed below.

\section{Magnetostratigraphic constraints}

Magnetostratigraphy of the Newark Supergroup in New Jersey (Kent et al., 1995) now provides what many consider the most complete record of magnetic field behavior for the Late Triassic and earliest Jurassic. Despite this, attempts to correlate other Late Triassic magnetostratigraphic columns to the Newark column are beset with problems that are currently a subject of ongoing discussion. In the Newark section, the Passaic palynofloral event corresponds to a short polarity reversal labeled E23r (Figs. 1, 7). There is a relatively long normal chron below the Passaic palynofloral event. The entire Newark extrusive zone is of normal polarity, and some sampling (not a complete magnetostratigraphic column) from sediments above the Newark extrusive zone indicates the presence of some short reversals.

At present, the only published magnetostratigraphic column that crosses the TJB in marine strata is at St. Audrie's Bay, England (Hesselbo et al., 2004; Hounslow et al., 2004). There is published magnetostratigraphy of marine Hettangian-Sinemurian strata in the Paris Basin (Yang et al., 1996), and Channell et al. (2003) assigned a Rhaetian age to some of the marine strata in Slovakia for which they published a magnetostratigraphy. Some magnetostratigraphy across the TJB in nonmarine strata of the Colorado Plateau, USA and in Morocco also has been published (Molina-Garza et al., 2003; Marzoli et al., 2004).

These magnetostratigraphic columns and other Upper Triassic columns document that the early-middle Norian is of mixed polarity, whereas the Rhaetian-Hettangian is mostly of normal polarity and punctuated by a few short reversed polarity intervals (e.g., Ogg, 2004a, Fig. 17.1). Straightforward magnetostratigraphic correlation of marine sections to the Newark magnetostratigraphic column has proven impossible (Krystyn et al., 2002; Channell et al., 2003; Muttoni et al., 2004; Gallet et al., 2007). For example, the magnetostratigraphy of the core from the Paris Basin indicates that essentially all of the Hettangian is of normal polarity with a few reversed intervals (Yang et al., 1996), but the supposedly Hettangian interval of the Newark Supergroup (including the Newark extrusive zone) is of normal polarity and lacks any reversals (Fig. 1). Most problematic have been attempts to correlate magnetostratigraphy from Upper Triassic marine strata that were deposited on the northern Tethyan margin (in Italy, Slovakia, Turkey, etc.) to the Newark magnetostratigraphy. The marine sections have many fewer reversals than does the Newark section for the same time interval. Given the differences in sedimentation rates between the marine strata and the Newark sections, and disagreement about biostratigraphic datum points that could be used to correlate the marine sections to the nonmarine Newark section, it is unlikely that replicatable correlations are possible.

Hounslow et al. (2004) presented the latest attempt to correlate a marine TJB section to the Newark section using magnetostratigraphy (Fig. 7). Their magnetostratigraphy of the section across the TJB at St. Audrie's Bay, England, indicates a dominantly normal polarity section from the Rhaetian through Hettangian, with four short intervals of reversed polarity below the marine TJB. Hounslow et al. (2004) suggested that either their SA5r reversal, which is the stratigraphically highest short reversed interval, or one of the stratigraphically lower 


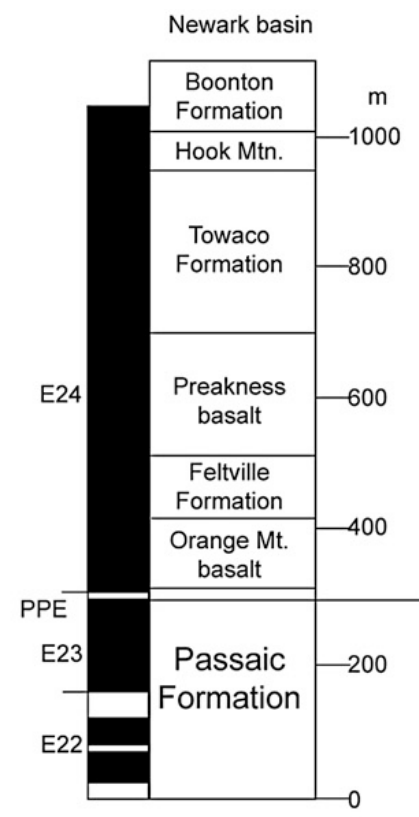

St. Audrie's Bay

Whiteside et al. (2006)
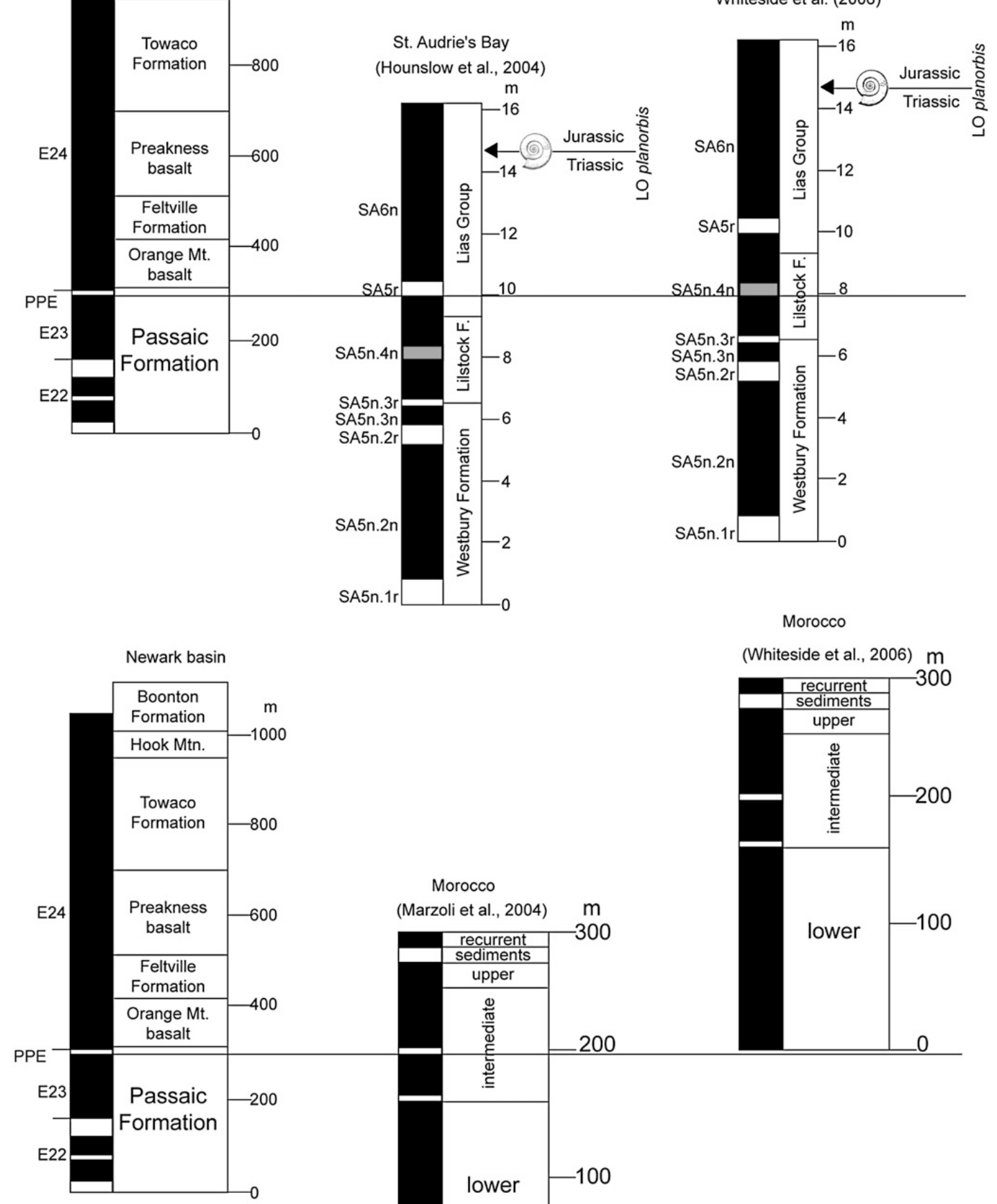

Morocco

(Whiteside et al., 2006) $\mathrm{m}$

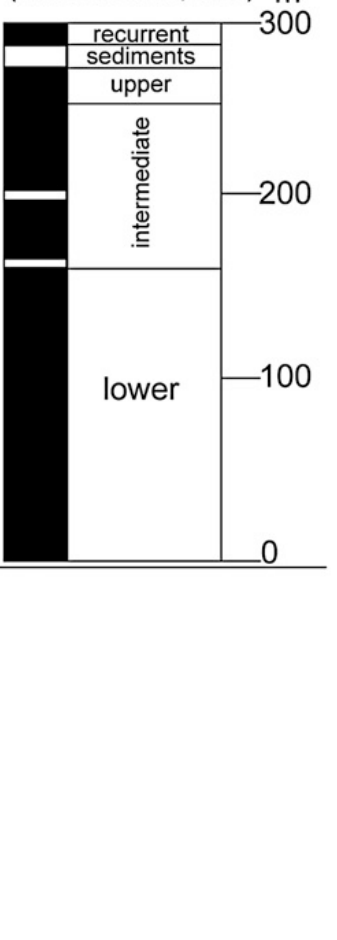

Fig. 7. Magnetostratigraphic correlations between the Newark basin and St. Audrie's Bay, England (above), and between the Newark basin and the CAMP basalt interval in the Central High Atlas of Morocco (below). In the correlation Newark to St. Audrie's Bay, the correlations advocated by Hounslow et al. (2004) and by Whiteside et al. (2007) are shown. Both indicate the base of the CAMP basalts in the Newark is older than the TriassicJurassic boundary. In the correlation Newark to Morocco, the correlations advocated by Marzoli et al. (2004) and by Whiteside et al. (2007) are shown. $\mathrm{LO}=$ lowest occurrence. 
reversals, SA5n.3r or SA5n.2R, correlate to the E23r reversal that corresponds to the Passaic palynofloral event in the Newark section (Fig. 8). All three possible correlations indicate the E23r reversal is older than the marine definition of the TJB, and correlation of the E23r reversal to the two lower reversals at St. Audrie's Bay is a correlation that would make E23r older than the stratigraphically highest conodonts and thus Late Triassic by any proposed definition of the TJB.

The problem with these magnetostratigraphic correlations, as Hounslow et al. (2004) conceded, is the lack of any unambiguous biostratigraphic tie-points between the Newark and St. Audrie's Bay sections to support a unique magnetostratigraphic correlation. Hounslow et al. (2004, p. 349) attempted to support synchrony of E23 $r$ and SA5r by equating the palynological change in the Newark at E23r to the palynological change in the upper Penarth Group. Alternatively, we suggest that this change could simply be a response to the upper Penarth Group transgression documented by Hesselbo et al. (2004) and is not a biostratigraphic datum. Indeed, Whiteside et al. (2007) correlated E23r to SA5n.3r based on correlating the Passaic palynofloral event to the pollen change in the Lilstock Formation. Either magnetostratigraphic correlation of E23r to the St. Audrie's Bay section indicates that E23r is older than the LO of P. planorbis (Fig. 7).

Marzoli et al. (2004) published new isotopic ages, magnetostratigraphy and palynostratigraphy for the CAMP basalt interval in the High Atlas of Morocco. Their data indicate a short magnetic reversal in a limestone bed interbedded with the basalt sheets that they correlated to E23r in the Newark section (Fig. 8). Marzoli et al. (2004) concluded that this indicates an onset of CAMP volcanism in Morocco demonstrably older than the oldest CAMP basalt sheet in the Newark basin. An alternative correlation would equate the basal CAMP basalts in New Jersey and Morocco and argue that the short reversal in the Moroccan section is present, but undetected in the Newark extrusive zone (Whiteside et al., 2007) (Fig. 7). Significantly, palynomorphs up to the base of the CAMP basalt sheet in Morocco are a P. densus assemblage of Late Triassic age. The limestone also yields some specimens of $P$. densus, but they may be reworked (Marzoli et al., 2004).

Marzoli et al. (2004) accepted the conclusion that the basal CAMP basalt sheet in New Jersey is of Jurassic age, so they argued for an older onset of CAMP volcanism in Morocco than in New Jersey. However, as argued here, there is no biostratigraphic evidence that the basal CAMP basalt in New Jersey is younger than latest Triassic, so the basal CAMP basalts in New Jersey and Morocco are, within biostratigraphic resolution, the same age.

Most recently, Gallet et al. (2007) presented a magnetostratigraphy of marine Rhaetian strata in southwestern Turkey that they correlate to other Tethyan sections and to the Newark magnetostratigraphic section of Kent et al. (1995). This section indicates that the Rhaetian (the "long Rhaetian" used here) is mostly of normal polarity with two short reversals near the middle. Gallet et al. (2007) concede the lack of robust data for much of the middle Norian in Tethyan section. Nonetheless, they propose two scenarios based on correlation of a long reversed interval from the end middle-Norian (Alaunian zone 3) to the Newark (either to the E17r or to the entire E17r-E20r interval). In both, the result is a possible sedimentary hiatus that eliminates much of the Rhaetian in the Newark basin and indicates the TJB is above the base of the lowest CAMP basalt. This proposal is consistent with the interpretation of Kozur and Weems (2005).

\section{Chemostratigraphic constraints}

\subsection{Carbon isotopes}

Significant negative excursions in the isotopic composition of organic matter occur in close proximity to the TJB in several marine sections, prompting the suggestion that isotope stratigraphy may be used to define the position of the TJB (Hesselbo et al., 2002, 2004). For example, at the Kennecott Point section in the Queen Charlotte Islands, Canada (Fig. 2), a pronounced negative $\delta^{13} \mathrm{C}$ excursion (of approximately $1.5-2.0 \%$ ) spans the $\mathrm{TJB}$, beginning immediately below the highest occurrence of Triassic ammonites and radiolarians, and continuing to above the lowest occurrence of Jurassic radiolarians (Ward et al., 2001, 2004; Williford et al., 2007). In the New York Canyon section of Nevada, USA (Fig. 2), a negative $\delta^{13} \mathrm{C}$ excursion of similar magnitude (about 2.0\%) also begins just below the highest occurrence of conodonts, Triassic ammonites (Choristoceras crickmayi and Arcestes spp.) and Triassic bivalves (Guex et al., 2003, 2004; Orchard et al., 2007). The sections at St. Audrie's Bay, southwest England (Hesselbo et al., 2002, 2004), Csövár, Hungary (Pálfy et al., 2000), and Tiefengraben, Austria (Kuerschner et al., 2006) also display negative $\delta^{13} \mathrm{C}$ excursions of approximately 2.0 to $3.0 \%$ that begin below the conodont HO. Although a similar trend has been claimed for several other sections based on the carbon-isotope composition of carbonate (e.g., Galli et al., 2005), the susceptibility of the isotopic composition of carbonate to diagenetic modification renders these data less reliable than that derived from 
organic carbon. In all sections, the lower isotope excursion is succeeded by an interval of strata in which the isotopic composition of the organic matter returns to previous values, or is enriched. This positive excursion is succeeded, in turn, by an interval again displaying depleted isotopic values. The widespread nature of the negative isotope excursion suggests a disruption of the carbon cycle of global extent. Indeed, a number of non-mutually exclusive scenarios have been proposed: a collapse of primary productivity has been suggested for the latest Triassic (Ward et al., 2001; Guex et al., 2004); the release of isotopically light volcanogenic $\mathrm{CO}_{2}$ from CAMP eruptions also has been considered, but generally rejected on mass balance considerations (Kump and Arthur, 1999; Beerling and Berner, 2002); the release of methane hydrate from seafloor sediments has become a particularly fashionable hypothesis (Pálfy et al., 2000; Hesselbo et al., 2002; Beerling and Berner, 2002; Tanner et al., 2004), although it suffers from a lack of predictive testability at present.

Guex et al. (2004) commented on the fact that the sections at St. Audrie's Bay and New York Canyon display a pattern of isotope variation in which the negative excursion described above is reversed by a strongly positive excursion in the overlying strata for several meters and then succeeded by a more extended negative excursion. This same trend is displayed in the recently published data from Kennecott Point and Tiefengraben (Williford et al., 2007; Kuerschner et al., 2007). Guex et al. (2004) offered the scenario that the shorter initial excursion, which they consider Rhaetian, resulted in part from a productivity collapse triggered by the adverse effects of CAMP volcanism; this excursion begins before but encompasses the ammonite, conodont, bivalve, and radiolarian extinctions.

If this idea is correct, linking the initial negative carbon isotope excursion to CAMP indicates that the CAMP must have begun in the Triassic. Recently, Kuerschner et al. (2007) documented that the initial isotope excursion at the base of the Tiefengraben Member of the Kendelbach Formation occurs in the Rhaetipolis-Porcellispora palynomorph zone, which they place in the Rhaetian on the basis of indisputable Triassic foraminifera. Additionally, these authors propose a convincing correlation to the St. Audrie's Bay section, based on the bifurcate shape of the lower isotopic excursion (also seen at New York Canyon and Kennecott Point), the highest occurrence of conodonts, and the lowest occurrence of Cerebropollenites thiergartii, which clearly places the initial excursion below the TJB. The succeeding positive excursion, in their scenario, marks a return to enhanced bioproductivity during a period of greenhouse warming.

Williford et al. (2007), in explaining a similar pattern in the Kennecott Point section, interpret a greenhouse- induced biocalcification crisis to explain the strongly positive excursion overlying the initial negative excursion. The later (Hettangian) excursion is more problematic, but is unlikely to have a catastrophic cause, in the view of the authors, because it encompasses an interval of evolutionary recovery and radiation, not extinction. Furthermore, the data of Williford et al. (2007) for Kennecott Point extend the isotope record stratigraphically higher than any other extant data set and demonstrate that the "main isotope excursion" is not an excursion at all, but in fact a prolonged trend of isotopically light organic matter that extends well into the Sinemurian.

A negative $\delta^{13} \mathrm{C}$ excursion for organic carbon in terrestrial environments also has been claimed for nonmarine strata encompassing the TJB (McElwain et al., 1999; Hesselbo et al., 2002; Whiteside et al., 2003, 2004). The presumption is that the marine excursion resulted from a drastic alteration of the $\delta^{13} \mathrm{C}$ of the global $\mathrm{CO}_{2}$ reservoir that similarly was recorded by vascular plants. However, published isotope analyses of plant macrofossils for TJB sections in Scania fail to exhibit this excursion (McElwain et al., 1999); data from Greenland display an apparent trend that appears to correlate with the marine data, although there is significant intersample $\delta^{13} \mathrm{C}$ variability and therefore a lack of the consistency that is displayed in the marine record (McElwain et al., 1999; Hesselbo et al., 2002). Notably, terrestrial organic matter displays significant interspecific variations in isotopic composition due to variations in the organic composition; thus, only species-specific or compound-specific analysis is likely to reveal a genuine change in isotopic composition (Kuerschner et al., 2007). Even so, variations in the isotopic composition of plants may result from environmental factors other than the $\delta^{13} \mathrm{C}$ of the atmosphere, as proposed by the above authors.

Uppermost Triassic nonmarine strata in the Newark and Fundy basins contain predominantly redbed sediments that are not conducive to the preservation of organic matter, so these sections have yielded only fragmentary carbon isotope data sets from the analysis of bulk samples (Whiteside et al., 2003, 2004). These data appear to show significant carbon isotope excursions coincident with the Passaic palynofloral event. If the carbon isotope excursion at the Passaic palynofloral event in the Newark correlates to that excursion at St. Audrie's Bay and in other marine sections, then the Passaic palynofloral event is Triassic, although such an isotope-based correlation is far from certain based on available data.

Despite the apparent widespread consistency of the isotope excursion that precedes and coincides with the final extinction of Triassic ammonites, conodonts, and other forms, it is essential to note that the isotope record 
for the upper Rhaetian through lower Hettangian displays complexities that vary from section to section; thus, application of the isotope excursion as a non-biostratigraphic marker is not yet straightforward. Serious questions regarding the relative contributions of terrestrial vs. marine organic components in sections that contain significant changes in sea level and facies have not been addressed sufficiently. Until these questions are answered, and until a robust carbon isotope record across the TJB is documented from nonmarine strata, the carbon isotope record cannot be used to correlate nonmarine and marine strata across the TJB with certainty.

\subsection{Osmium and strontium isotopes}

Cohen and Coe $(2002,2007)$ attempted to better constrain the temporal relationship between extinctions across the TJB and the onset of CAMP volcanism by analyzing the section at St Audrie's Bay for the concentration of ${ }^{192} \mathrm{Os}$ and for the ratio ${ }^{187} \mathrm{Os} /{ }^{188} \mathrm{Os} .{ }^{192} \mathrm{Os}$ is an unradiogenic isotope, derived from igneous activity, that has a very short residence time in the ocean and thus could be a sedimentary indicator of the onset of the CAMP eruptions. The ratio ${ }^{187} \mathrm{Os} /{ }^{188} \mathrm{Os}$ reflects the relative contributions of radiogenic ${ }^{187} \mathrm{Os}$ from the weathering of continental crust and unradiogenic ${ }^{188} \mathrm{Os}$ from the alteration of mantle-derived (mafic) igneous material. Unfortunately, the Lilstock Formation at St. Audrie's Bay contains no lithologies suitable for these analyses, so there is a significant hiatus in the data. The data for ${ }^{192}$ Os concentration display an increase simultaneous with a decrease in the ${ }^{187} \mathrm{Os} /{ }^{188} \mathrm{Os}$ ratio in the lower pre-planorbis beds, above the top of the Lilstock Formation and well above the initial carbon isotope excursion. Therefore, these data either do not demonstrate a clear connection between the isotope excursion and the onset of CAMP activity or they could indicate the onset of CAMP in the Late Triassic.

The $\mathrm{Sr}$ isotope ratio of seawater is thought to reflect the relative contributions of $\mathrm{Sr}$ derived from hydrothermal alteration of ocean crust at the mid-ocean ridges and the weathering on land of ancient continental crust. Because the rate of formation and alteration of ocean crust is considered invariant over shorter time scales (less than a few million years), the flux of the ratio ${ }^{87} \mathrm{Sr} /{ }^{86} \mathrm{Sr}$ primarily reflects variations in rates of terrestrial chemical weathering (see McArthur et al., 2001 compilation). Cohen and Coe (2007, Fig. 4) show marked changes in $\mathrm{Sr}$ and Os ratios beginning before $(\mathrm{Os})$ and at $(\mathrm{Sr})$ the beginning of the negative carbon isotope excursion at St. Audrie's Bay. These are Triassic events, and suggest a latest Triassic onset of CAMP volcanism.

\subsection{Iridium enrichment}

Olsen et al. (2002a,b) reported an elevated level of iridium, up to a maximum of $285 \mathrm{pg} / \mathrm{g}$, that correlates with the Passaic palynofloral event in the upper Passaic Formation in the Newark basin. This "modest iridium anomaly," in a smectitic claystone, is greater by an order of magnitude than the average crustal abundance, although it is still one to two orders of magnitude smaller than the anomaly reported at the $\mathrm{K}-\mathrm{T}$ boundary (Alvarez et al., 1980).

Tanner and Kyte (2005) reported a pattern of enrichment in siderophile elements, including Ir, at multiple horizons in strata of the Fundy basin coinciding closely with the Passaic palynofloral event identified by Fowell and Traverse (1995) in the Partridge Island section. Concentrations of iridium increase to a maximum of $355 \mathrm{pg} / \mathrm{gm}$ approximately $10 \mathrm{~cm}$ below this horizon, and specifically, Ir enrichment appears to correlate with the organic content of the host sediments. Tanner and Kyte (2005) speculated that the observed Ir enrichment was derived from CAMP volcanism, rather than an extraterrestrial source, and that the enrichment was controlled by redox boundary conditions within the sedimentary succession. Other platinum group elements co-vary with iridium in the Partridge Island section, increasing by 50 to $100 \%$ between the top of the section to the palynological boundary. However, the ratios observed are more typical of igneous processes than of a chondritic source. There are no reports of iridium enrichment of similar magnitude at any of the marine TJB sections (Tanner et al., 2004).

Olsen et al. (2002b) discounted a volcanic source for the anomaly on the basis of a lack of correlation of iridium concentration with other trace elements in the Newark basin section. However, a similar lack of correlation is observed between iridium and other siderophile elements, such as cobalt, nickel, or chromium, which are potential indicators of an extraterrestrial origin (Koeberl, 1998; Kyte, 2002; Olsen et al., 2002b). No impact-related grains have been identified at the Passaic palynofloral event in the Fundy or Newark basins, nor are there any independently verified reports of impact grains in association with the TJB at any location (Mossman et al., 1998; Tanner et al., 2004). At present, the data do not allow discrimination among possible sources of the iridium, so no correlation based on iridium anomalies is possible.

\section{Conclusion: one Triassic-Jurassic boundary}

There can only be one TJB, and this is the boundary defined in the marine section by marine biostratigraphic 


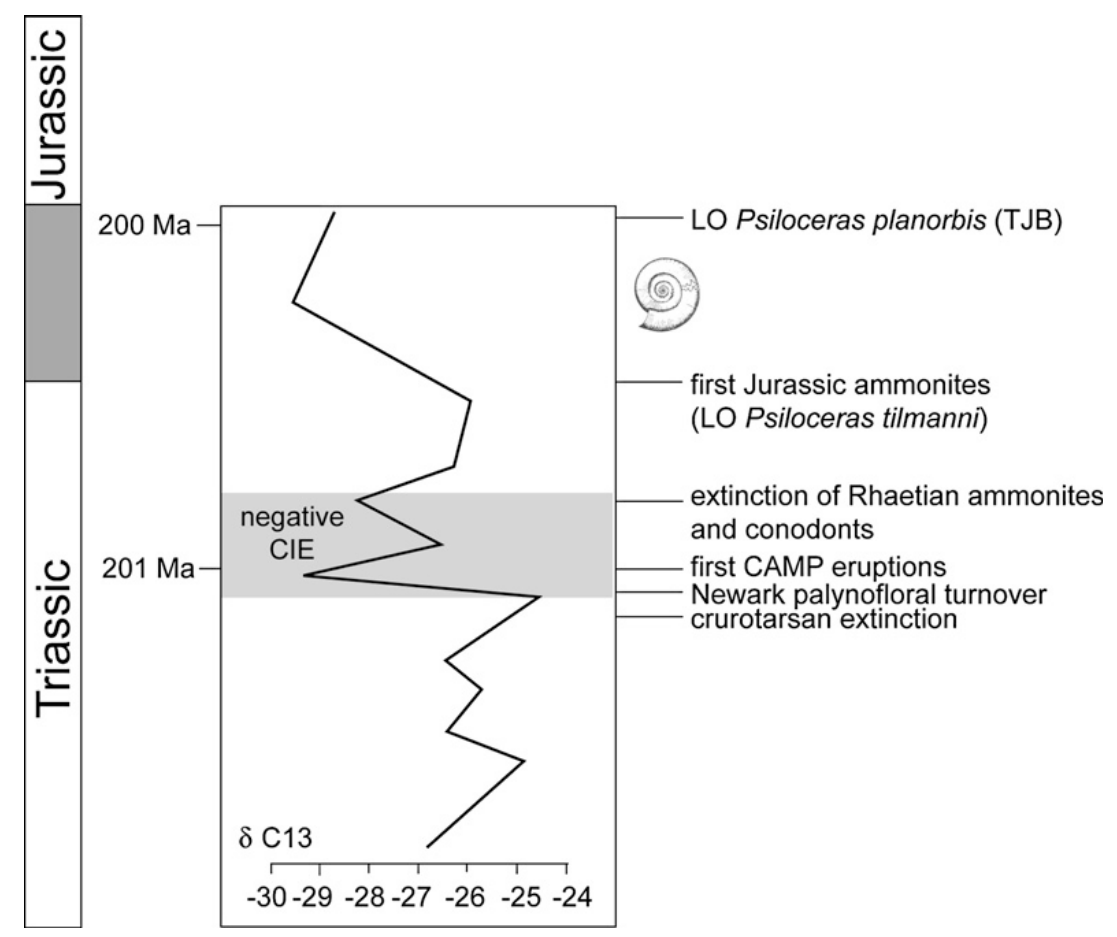

Fig. 8. Succession of nonmarine and marine events around the Triassic-Jurassic boundary. Isotope curve is based on St Audrie's Bay section, after Hesselbo et al. (2004). LO = lowest occurrence.

criteria. At present, this boundary is defined by the lowest occurrence of the psiloceratid ammonite P. planorbis in southern England. Palynostratigraphy provides no precise and broadly correlateable event that corresponds to the marine TJB. Changes in palynomorph assemblages across the TJB are diachronous and typically driven by local/regional marine transgressions and climate changes. The Passaic palynofloral event in the Newark Supergroup below the CAMP basalts does not correlate to the TJB and is most likely a late Norian or Rhaetian event. In the Newark Supergroup, all biostratigraphic evidence indicates the TJB is within or just above the Newark extrusive zone. Furthermore, radioisotopic ages, magnetostratigraphy and chemostratigraphic constraints indicate the TJB is above the lowest CAMP basalt in the Newark Supergroup. All data converge to place the TJB in the Newark extrusive zone, and thus indicate that CAMP volcanism began during the latest Triassic.

Correct placement of the TJB in the Newark Supergroup allows, for the first time, a temporal sequencing of key nonmarine and marine events across the TJB (Fig. 8). Consequently, the extinction of crurotarsans, which is the substantial tetrapod extinction at the end of the Triassic, is a Late Triassic event that predates the palynofloral turnover in the Newark (Passaic palynofloral event) before the onset of CAMP volcanism. The CAMP eruptions are coincident (within resolution) with a negative carbon isotope excursion detected in many marine sections, and this suggests that CAMP disrupted the global carbon system. However, the actual final extinction of conodonts and Rhaetian ammonites postdates the beginning of the negative carbon isotope excursion (Guex et al., 2004), and this suggests that it was not a sudden and synchronous result of the onset of CAMP volcanism. The first Jurassic ammonites appear after the conodont and Rhaetian ammonite extinctions. All of these events took place in a 1 to 2 myr time-span. Their sequencing suggests that nonmarine extinctions and marine extinctions across the TJB were definitely not synchronous.

\section{Acknowledgements}

Discussions and collaboration with numerous workers influenced the ideas presented here. In particular, we acknowledge A. B. Heckert, P. Huber and A. P. Hunt. Careful reviews by Mark Hounslow and Jim Ogg improved the manuscript.

\section{References}

Alvarez, L.W., Alvarez, W., Asaro, F., Michel, H.V., 1980. Extraterrestrial cause for the Cretaceous-Tertiary extinction. Science 208, 1095-1108.

Ash, S., 1986. Fossil plants and the Triassic-Jurassic boundary. In: Padian, K. (Ed.), The Beginning of the Age of Dinosaurs. Cambridge University Press, Cambridge, UK, pp. 21-30. 
Barnard, P.D.W., 1973. Mesozoic floras. Special Papers in Palaeontology $12,175-187$.

Beerling, D.J., Berner, R.A., 2002. Biogeochemical constraints on the Triassic-Jurassic boundary carbon cycle event. Global Biogeochemical Cycles 16, 101-113.

Benton, M.J., 1994. Late Triassic to Middle Jurassic extinctions among continental tetrapods: testing the pattern. In: Fraser, N.C., Sues, H-D. (Eds.), In the Shadow of the Dinosaurs. Cambridge University Press, Cambridge, UK, pp. 366-397.

Brugman, W.A., 1983. Permian-Triassic Palynology. State University Utrecht, Utrecht. $121 \mathrm{pp}$.

Chang, W., Chen, P., Shen, Y., 1976. Fossil Conchostraca of China. Science Press, Beijing. 325 pp.

Channell, J.E.T., Kozur, H.W., Sievers, T., Mock, R., Aubrecht, R., Sykora, M., 2003. Carnian-Norian bio-magnetostratigraphy at Silicka Brezova (Slovakia): correlation to other Tethyan sections and to the Newark basin. Palaeogeography, Palaeoclimatology, Palaeoecology 191, 65-109.

Chen, P., Shen, Y., 1985. Fossil Conchostraca. Science Press, Beijing. $241 \mathrm{pp}$.

Cleal, C.J., 1993a. Pteridophyta. In: Benton, M.J. (Ed.), The Fossil Record 2. Chapman \& Hall, London, pp. 779-794.

Cleal, C.J., 1993b. Gymnospermophyta. In: Benton, M.J. (Ed.), The Fossil Record 2. Chapman \& Hall, London, pp. 795-808.

Cohen, A.S., Coe, A.L., 2002. New geochemical evidence for the onset of volcanism in the Central Atlantic magmatic province and environmental change at the Triassic-Jurassic boundary. Geology $30,267-270$.

Cohen, A.S., Coe, A.L., 2007. The impact of the Central Atlantic magmatic province on climate and on the $\mathrm{Sr}$ - and Os-isotope evolution of seawater. Palaeogeography, Palaeoclimatology, Palaeoecology 244, 374-390.

Colbert, E.H., 1949. Progressive adaptations as seen in the fossil record. In: Jepsen, G.L., Mayr, E., Simpson, G.G. (Eds.), Genetics, Paleontology and Evolution. Princeton University Press, Princeton, NJ, pp. 390-402.

Colbert, E.H., 1958. Triassic tetrapod extinction at the end of the Triassic Period. Proceedings of the National Academy of Sciences of the United States of America 44, 973-977.

Cope, J.C.W., Getty, T.A., Howarth, M.K., Morton, N., Torrens, H.S., 1980. A correlation of Jurassic rocks in the British Isles. Part one: introduction and Lower Jurassic. Special Report - Geological Society of London 14 (73 pp.).

Cornet, B. 1977. The palynostratigraphy and age of the Newark Supergroup. Ph.D. Thesis. Pennsylvania State University, University Park, PA. 505 pp.

Cornet, B., Olsen, P.E., 1985. A summary of the biostratigraphy of the Newark Supergroup of eastern North America with comments on provinciality. In: Weber III, R. (Ed.), Congreso Latinoamericano de Paleontologia Mexico, Simposio Sobre Floras del Triasico Tardio, su Fitogeografia y Palecologia, Memoria. UNAM Instituto de Geologia, Mexico City, pp. 67-81.

Cornet, B., Traverse, A., 1975. Palynological contributions to the chronology and stratigraphy of the Hartford basin in Connecticut and Masachusetts. Geoscience and Man 11, 1-33.

Cornet, B., Traverse, A., McDonald, N.G., 1973. Fossil spores, pollen, and fishes from, Connecticut indicate early Jurassic age for part of the Newark Group. Science 182, 1243-1247.

Dunning, G.R., Hodych, J.P., 1990. U-Pb zircon and baddeleyite ages for the Palisades and Gettsyburg sills of the northeastern United States: Implications for the age of the Triassic-Jurassic boundary. Geology 18, 795-798.
Edwards, D., 1993. Bryophyta. In: Benton, M.J. (Ed.), The Fossil Record 2. Chapman \& Hall, London, pp. 775-778.

Fisher, M.J., Dunay, R.E., 1981. Palynology and the Triassic/ Jurassic boundary. Review of Palaeobotany and Palynology 34, 129-135.

Forster, S.C., Warrington, G., 1985. Geochronology of the Carboniferous, Permian and Triassic. In: Snelling, N.J. (Ed.), The Chronology of the Geological Record. The Geological Society Memoir, vol. 10. Blackwell, London, pp. 99-113.

Fowell, S.J. 1994. Palynology of Triassic/Jurassic boundary sections from the Newark Supergroup of eastern North America: Implications for catastrophic extinction scenarios, Columbia University, $\mathrm{PhD}$. Dissertation. $143 \mathrm{pp}$.

Fowell, S.J., Olsen, P.E., 1993. Time calibration of Triassic-Jurassic microfloral turnover, eastern North America. Tectonophysics 222, 361-369.

Fowell, S.J., Olsen, P.E., 1995. Time calibration of Triassic/Jurassic microfloral turnover, eastern North America - comment. Tectonophysics $245,96-99$.

Fowell, S.J., Traverse, A., 1995. Palynology and age of the upper Blomidon Formation, Fundy basin, Nova Scotia. Review of Palaeobotany and Palynology 86, 211-233.

Fowell, S.J., Cornet, B., Olsen, P.E., 1994. Geologically rapid Late Triassic extinctions: palynological evidence from the Newark Supergroup. Special Paper - Geological Society of America 288, 197-206.

Gallet, Y., Krystyn, L., Marcoux, J., Besse, J., 2007. New constraints on the end-Triassic (Upper Norian-Rhaetian) magnetostratigraphy. Earth and Planetary Science Letters 255, 458-470.

Galli, M.T., Jadoul, F., Bernasconi, S.M., Weissert, H., 2005. Anomalies in global carbon cycling and extinction at the Triassic/ Jurassic boundary: evidence from a marine C-isotope record. Palaeogeography, Palaeoclimatology, Palaeoecology 16, 203-214.

Gómez, J.J., Goy, A., Barrón, E., 2007. Events around the TriassicJurassic boundary in northern and eastern Spain: a review. Palaeogeography, Palaeoclimatology, Palaeoecology 244, 89-110.

Gradstein, F.M., Agterberg, F.P., Ogg, J.G., Hardenbol, J., van Veen, P., Thierry, J., Huang, Z., 1994. A Mesozoic time scale. Journal of Geophysical Research 99, 24051-24074.

Gradstein, F.M., Ogg, J.G., Smith, A.G., Bleeker, W., Lourens, L.J., 2004. A new geologic time scale with special reference to the Precambrian and Neogene. Episodes 27, 83-100.

Guex, J., Bartolini, A., Atudorei, V., Taylor, D., 2003. Two negative $\delta^{13} \mathrm{C}_{\text {org }}$ excursions near the Triassic-Jurassic boundary in the New York Canyon area (Gabbs Valley Range, Nevada). Bulletin de Géologie Lausanne 360, 1-4.

Guex, J., Bartolini, A., Atudorei, V., Taylor, D., 2004. High-resolution ammonite and carbon isotope stratigraphy across the TriassicJurassic boundary at New York Canyon (Nevada). Earth and Planetary Science Letters 225, 29-41.

Hallam, A., 2002. How catastrophic was the end-Triassic mass extinction? Lethaia 35, 147-157.

Hallam, A., Wignall, P.B., 1997. Mass Extinctions and their Aftermath. Oxford University Press, Oxford. 320 pp.

Hames, W.E., Renne, P.R., Ruppel, C., 2000. New evidence for geologically instantaneous emplacement of earliest Jurassic Central Atlantic magmatic province basalts on the North American margin. Geology 28, 859-862.

Harris, T.M., 1937. The fossil flora of Scoresby Sound East Greenland, Part 5: Stratigraphic relations of the plant beds. Meddelelser om Grønland 112, 1-112.

Haubold, H., 1971. Ichnia Amphibiorum and Reptiliorum fossilium. Encyclopedia of Paleoherpetology 18, 1-124. 
Haubold, H., 1986. Archosaur footprints at the terrestrial TriassicJurassic transition. In: Padian, K. (Ed.), The Beginning of the Age of Dinosaurs. Cambridge University Press, Cambridge, pp. 189-201.

Hesselbo, S.P., Robinson, S.A., Surlyk, F., Piasecki, S., 2002. Terrestrial and marine extinction at the Triassic-Jurassic boundary synchronized with major carbon-cycle perturbation: a link to initiation of massive volcanism? Geology 30, 251-254.

Hesselbo, S.P., Robinson, S.A., Surlyk, F., 2004. Sea-level changes and facies development across potential Triassic-Jurassic boundary horizons, SW Britain. Journal of the Geological Society (London) 161, 365-379.

Hounslow, M.W., Posen, P.E., Warrington, G., 2004. Magnetostratigraphy and biostratigraphy of the Upper triassic and lowermost Jurassic succession, St. Audrie's Bay, UK. Palaeogeography, Palaeoclimatology, Palaeoecology 213, 331-358.

Huber, P., Lucas, S.G., Hunt, A.P., 1993a. Late Triassic fish assemblages of the North American Western Interior. Museum of Northern Arizona Bulletin 59, 51-66.

Huber, P., Lucas, S.G., Hunt, A.P., 1993b. Vertebrate biochronology of the Newark Supergroup Triassic, eastern North America. New Mexico Museum of Natural History and Science Bulletin 3, 179-186.

Hughes, N.F., 1976. Palaeobiology of Angiosperm Origins: Problems of Mesozoic Seed-plant Evolution. Cambridge University Press, Cambridge. 242 pp.

Kelber, K.-P., 1998. Phytostratigraphische aspekte der makrofloren des süddeutschen Keupers. Documenta Naturae 117, 89-115.

Kent, D.V., Olsen, P.E., 1999. Astronomically tuned geomagnetic polarity time scale for the Late Triassic. Journal of Geophysical Research 104, 12831-12841.

Kent, D.V., Tauxe, L., 2005. Corrected Late Triassic latitudes for continents adjacent to the North Atlantic. Science 307, 220-244.

Kent, D.V., Olsen, P.E., Witte, W.K., 1995. Late Triassic-earliest Jurassic geomagnetic polarity sequence and paleolatitudes from drill cores in the Newark rift basin, eastern North America. Journal of Geophysical Research 100, 14,965-14,998.

Knight, K.B., Nomade, S., Renne, P.R., Marzoli, A., Bertrand, H., Youbi, N., 2004. The Central Atlantic magmatic province at the Triassic-Jurassic boundary: Paleomagnetic and 40Ar/39Ar evidence from Morocco for brief, episodic volcanism. Earth and Planetary Science Letters 228, 143-160.

Knoll, A.H., 1984. Patterns of extinction in the fossil record of vascular plants. In: Nitecki, M.H. (Ed.), Extinction. University of Chicago Press, Chicago, pp. 21-68.

Koeberl, C., 1998. Identification of meteoritic components in impactites. In: Grady, M.M., Hutchison, R., McCall, G.J.H., Rothery, D.A. (Eds.), Meteorites: Flux with Time and Impact Effects. Geological Society (London) Special Publication, vol. 140, pp. 133-153.

Kozur, H.W., Weems, R.E., 2005. Conchostracan evidence for a late Rhaetian to early Hettangian age for the CAMP volcanic event in the Newark Supergroup, and a Sevatian (late Norian) age for the immediately underlying beds. Hallesches Jahrbuch Geowissenschaften B27, 21-51.

Krystyn, L., Gallet, Y., Besse, J., Marcoux, J., 2002. Integrated upper Carnian to lower Norian biochronology and implications for the Upper Triassic magnetic polarity time scale. Earth and Planetary Science Letters 203, 343-351.

Kuerschner, W.M., Bonis, N.R., Krystyn, L., 2007. Carbon-isotope stratigraphy and palynostratigraphy of the Triassic-Jurassic transition in the Tiefengraben section-Northern Calcareous Alps (Austria). Palaeogeography, Palaeoclimatology, Palaeoecology $244,257-280$.
Kump, L.R., Arthur, M.A., 1999. Interpreting carbon-isotope excursions: carbonates and organic matter. Chemical Geology 161, 181-198.

Kyte, F.T., 2002. Tracers of the extraterrestrial component in sediments and inferences for Earth's accretion history. In: Koeberl, C., MacLeod, K. (Eds.), Catastrophic Events and Mass Extinctions: Impacts and Beyond. Geological Society America Special Paper, vol. 356, pp. 21-28.

Litwin, R.J., Traverse, A., Ash, S.R., 1991. Preliminary palynological zonation of the Chinle Formation, southwestern U.S.A., and its correlation to the Newark Supergroup (eastern U.S.A.). Review of Palaeobotany and Palynology 68, 269-287.

Lloyd, A.J., 1964. The Luxembourg Colloquium and the revision of the stages of the Jurassic System. Geological Magazine 101, 249-259.

Lockley, M.G., Hunt, A.P., 1994. A review of Mesozoic vertebrate ichnofaunas of the western Interior United States: evidence and implications of a superior track record. In: Caputo, M.V., Peterson, J.A., Franczyk, K.J. (Eds.), Mesozoic Systems of the Rocky Mountain region: RMS-SEPM, Denver, pp. 95-108.

Lorenz, J.C., 1988. Triassic-Jurassic Rift-basin Sedimentology. Van Nostrand Reinhold, New York. 315 pp.

Lucas, S.G., 1994. Triassic tetrapod extinctions and the compiled correlation effect. Memoir - Canadian Society of Petroleum Geologists 17, 869-875.

Lucas, S.G., 1996. The thyreophoran dinosaur Scelidosaurus from the Lower Jurassic Lufeng Formation, Yunnan, China. Museum of Northern Arizona Bulletin 60, 81-85.

Lucas, S.G., 1997. Upper Triassic Chinle Group, western United States: a nonmarine standard for Late Triassic time. In: Dickins, J.M., Yang, Z., Yin, H., Lucas, S.G., Acharyya, S.K. (Eds.), Late Palaeozoic and Early Mesozoic Circum-Pacific Events and their Global Correlation. Cambridge Univerity Press, Cambridge, pp. 209-228.

Lucas, S.G., 1998. Global Triassic tetrapod biostratigraphy and biochronology. Palaeogeography, Palaeoclimatology, Palaeoecology $143,347-384$.

Lucas, S.G., 1999. Tetrapod-based correlation of the nonmarine Triassic. Zentralblatt für Geologie und Paläontologie, Teil 1: Allgemeine, Angewandte, Regionale und Historische Geologie $7-8,497-521$.

Lucas, S.G., 2006. Toward a global Jurassic tetrapod biochronology. Volumina Jurassica 4, 123.

Lucas, S.G., Huber, P., 2003. Vertebrate biostratigraphy and biochronology of the nonmarine Late Triassic. In: LeTourneau, P.M., Olsen, P.E. (Eds.), The Great Rift Valleys of Pangea in Eastern North America. Sedimentology, Stratigraphy, and Paleontology, vol. 2. Columbia University Press, New York, pp. 143-191.

Lucas, S.G., Kirkland, J.I., 1998. Preliminary report on Conchostraca from the Upper Jurassic Morrison Formation, western United States. Modern Geology 22, 415-422.

Lucas, S.G., Milner, A.R.C., 2006. Conchostraca from the Lower Jurassic Whitmore Point Member of the Moenave Formation, Johnson Farm, southwestern Utah. New Mexico Museum of Natural History and Science Bulletin 37, 421-423.

Lucas, S.G., Tanner, L.H., 2004. Late Triassic extinction events. Albertiana 31, 31-40.

Lucas, S.G., Tanner, L.H., 2007. Tetrapod biostratigraphy and biochronology of the Triassic-Jurassic transition on the southern Colorado Plateau, USA. Palaeogeography, Palaeoclimatology, Palaeoecology 244, 242-256.

Lucas, S.G., Guex, J., Tanner, L.H., Taylor, D., Kuerschner, W.M., Atudorei, V., Bartolini, A., 2005. Definition of the TriassicJurassic boundary. Albertiana 32, 12-16. 
Lucas, S.G., Klein, H., Lockley, M.G., Spielmann, J.A., Gierlinski, G., Hunt, A.P., Tanner, L.H., 2006. Triassic-Jurassic stratigraphic distribution of the theropod footprint ichnogenus Eubrontes. New Mexico Museum of Natural History and Science Bulletin $37,86-93$.

Lund, J.J., 1977. Rhaetian to lower Liassic palynology of the onshore south-eastern North Sea Basin. Geological Survey of Denmark. 2. Series 109, 1-105.

Marzoli, A., Bertrand, H., Knight, K.B., Cirilli, S., Buratti, N., Vérati, C., Nomade, S., Renne, P.R., Youbi, N., Martini, R., Allenbach, J., Neuwerth, R., Rapaille, C., Zaninetti, L., Bellieni, G., 2004. Synchrony of the Central Atlantic magmatic province and the Triassic-Jurassic boundary climatic and biotic crisis. Geology 32, 973-976.

Maubeuge, P.-L., 1964. Résolutions du colloque. In: Maubeuge, P. (Ed.), Colloque du Jurassique à Luxembourg 1962. Ministère des Arts et des Sciences, Luxembourg, pp. 77-80.

McArthur, J.M., Howarth, R.J., Bailey, T.R., 2001. Strontium isotope stratigraphy: LOWESS version 3: Best fit to the marine Sr-isotope curve for 0-509 Ma and accompanying look-up table for deriving numerical age. Journal of Geology 109, 155-170.

McElwain, J.C., Beerling, D.J., Woodward, F.I., 1999. Fossil plants and global warming at the Triassic-Jurassic boundary. Science 285, 1386-1390.

Menning, M., 1989. A synopsis of numerical timescales 1917-1986. Episodes 12, 3-4.

Milner, A.R.C., Kirkland, J.I., Birthisel, T.A., 2006. The geographic distribution and biostratigraphy of Late Triassic-Early Jurassic freshwater fish faunas of the southwestern United States. New Mexico Museum of Natural History and Science Bulletin 37, 522-529.

Min, K., Mundil, R., Renne, P.R., Ludwig, K.R., 2005. A test for the systematic errors in ${ }^{40} \mathrm{Ar} /{ }^{39} \mathrm{Ar}$ geochronology through comparison with $\mathrm{U} / \mathrm{Pb}$ analysis of a 1.1-Ga rhyolite. Geochimica et Cosmochimica Acta 64, 73-98.

Molina-Garza, R.S., Geissman, J.W., Lucas, S.G., 2003. Paleomagnetism and magnetostratigraphy of the lower Glen Canyon and upper Chinle Groups, Jurassic-Triassic of northern Arizona and northeast Utah. Journal of Geophysical Research 108 (B4), 2181. doi:10.1029/2002JB001909.

Morbey, J.S., 1975. The palynostratigraphy of the Rhaetian stage, Upper Triassic in the Kendelbachgraben, Austria. Palaeontographica B 152, 1-75.

Morbey, J.S., 1978. Late Triassic and Early Jurassic subsurface palynostratigraphy in northwestern Europe. Palinologia 1, 355-365.

Morbey, S.J., Neves, R., 1974. A scheme of palynologically defined concurrent range zones and subzones for the Triassic Rhaetian stage (sensu lato). Review of Palaeobotany and Palynology 17, 161-173.

Mossman, D.J., Graham, R.G., Lagenhorst, F., 1998. A search for shocked quartz at the Triassic-Jurassic boundary in the Fundy and Newark basins of the Newark Supergroup. Canadian Journal of Earth Sciences 35, 101-109.

Mostler, H., Scheuring, R., Ulrichs, M., 1978. Zur Mega-, Mikrofauna und Mikroflora der Kossenen Schichten (alpine Obertrias) von Weissloferbach in Tirol unter besonderer Berucksichtigung der in der suessi-und marshi-Zone auftreitenden Conodonten. Osterreichische Akademie der Wissenschaften Erdwissenschaftliche Kommission Schriftenreihe 4, 141-174.

Muttoni, G., Kent, D.V., Olsen, P.E., Di Stefano, P., Lowrie, W., Bernasconi, S.M., Hernandez, F.M., 2004. Tethyan magnetostratigraphy from Pizza Mondello (Sicily) and correlation to the Late Triassic Newark astrochronological polarity time scale. Geological Society of America Bulletin 116, 1043-1058.
Niklas, K.J., Tiffney, B.H., Knoll, A.H., 1983. Patterns in vascular land plant diversification: a statistical analysis at the species level. Nature 303, 614-616.

Nomade, S., Knight, K.B., Beutel, E., Renne, P.R., Vérati, C., Féraud, G., Marzoli, A., Youbi, N., Bertrand, H., 2007. Chronology of the Central Atlantic magmatic province: implications for the Central Atlantic rifting processes and the Triassic-Jurassic biotic crisis. Palaeogeography, Palaeoclimatology, Palaeoecology 326-344.

Ogg, J.G., 2004a. The Triassic period. In: Gradstein, F.M., Ogg, J.G., Smith, A.G. (Eds.), A Geologic Time Scale. Cambridge University Press, Cambridge, pp. 271-306.

Ogg, J.G., 2004b. The Jurassic Period. In: Gradstein, F.M., Ogg, J.G., Smith, A.G. (Eds.), A Geologic Time Scale 2004. Cambridge University Press, Cambridge, pp. 307-343.

Olsen, P.E., Galton, P.M., 1977. Triassic-Jurassic extinctions: are they real? Science 197, 983-986.

Olsen, P.E., Galton, P.M., 1984. A review of the reptile and amphibian assemblages from the Stormberg of South Africa, with special emphasis on the footprints and the age of the Stormberg. Paleontologica Africana 25, 87-110.

Olsen, P.E., Kent, D., 1999. Long-period Milankovitch cycles from the Late Triassic and Early Jurassic of eastern North America and their implications for the calibration of the early Mesozoic time-scale and the long-term behaviour of the planets. Philosophical Transactions - Royal Society. Mathematical, Physical and Engineering Sciences 357, 1761-1786.

Olsen, P.E., Sues, H-D., 1986. Correlation of continental Late Triassic and Early Jurassic sediments, and patterns of the Triassic-Jurassic tetrapod transition. In: Padian, K. (Ed.), The Beginning of the Age of Dinosaurs. Cambridge University Press, Cambridge, UK, pp. 321-351.

Olsen, P., McCune, A.R., Thomson, K.S., 1982. Correlation of the early Mesozoic Newark Supergroup by vertebrates, principally fishes. American Journal of Science 282, 1-44.

Olsen, P.E., Shubin, N.H., Anders, M.H., 1987. New Early Jurassic tetrapod assemblages constrain Triassic-Jurassic tetrapod extinction event. Science 237, 1025-1029.

Olsen, P.E., Fowell, S.J., Cornet, B., 1990. The Triassic/Jurassic boundary in continental rocks of eastern North America; a progress report. Special Paper - Geological Society of America 247, 585-593.

Olsen, P.E., Kent, D.V., Cornet, B., Witte, W.K., Schlische, R.W., 1996. High-resolution stratigraphy of the Newark rift basin (early Mesozoic, eastern North America). Geological Society of America Bulletin 108, 40-77.

Olsen, P.E., Smith, J.B., McDonald, N.G., 1998. Type material of the type species of the classic theropod footprint genera Eubrontes, Anchisauripus, and Grallator (Early Jurassic, Hartford and Deerfield basins, Connecticut and Massachusetts, U.S.A.). Journal of Vertebrate Paleontology 18, 586-601.

Olsen, P.E., Kent, D.V., Sues, H.D., Koeberl, C., Huber, H., Montanari, A., Rainforth, E.C., Powell, S.J., Szajna, M.J., Hartline, B.W., 2002a. Response to comment on "Ascent of dinosaurs linked to an iridium anomaly at the Triassic-Jurassic boundary. Science 296, 1305-1307.

Olsen, P.E., Koeberl, C., Huber, H., Montanari, A., Fowell, S.J., EtTouhani, M., Kent, D.V., 2002b. The continental Triassic-Jurassic boundary in central Pangea: recent progress and preliminary report of an Ir anomaly. Special Paper - Geological Society of America 356, 505-522.

Olsen, P.E., Kent, D.V., Sues, H.D., Koeberl, C., Huber, H., Montanari, A., Rainforth, E.C., Powell, S.J., Szajna, M.J., Hartline, B.W., 2003. Response to comment on Ascent of dinosaurs linked to an 
iridium anomaly at the Triassic-Jurassic boundary. Science 301, $169 \mathrm{c}$.

Olsen, P.E., Whiteside, J.H., Fedak, T., 2005. Field Trip A7: the Triassic-Jurassic faunal and floral transition in the Fundy Basin, Nova Scotia. Geological Association of Canada, Mineralogical Association of Canada, Canadian Society of Petroleum Geologists, Canadian Society of Soil Sciences Joint Meeting, Halifax, May 2005. AGS Special Publication, vol. 26. 53 pp.

Orbell, G., 1973. Palynology of the British Rhaeto-Liassic. Bulletin Geological Society Great Britain 44, 1-44.

Orchard, M.J., Carter, E.S., Lucas, S.G., Taylor, D.G., 2007. Rhaetian (Upper Triassic) conodonts and radiolarians from New York Canyon, Nevada, USA. Albertiana 35, 59-65.

Pálfy, J., Mundil, R., 2006. The age of the Triassic/Jurassic boundary: new data and their implications for the extinction and recovery. Volumina Jurassica 4, 294.

Pálfy, J., Smith, P.L., Mortensen, J.K., Friedman, R.M., 1999. Integrated ammonite biochronology and $\mathrm{U}-\mathrm{Pb}$ geochronometry from a basal Jurassic section in Alaska. Geological Society of America Bulletin 111, 1537-1549.

Pálfy, J., Mortensen, J.K., Carter, E.S., Smith, P.L., Friedman, R.M., Tipper, H.W., 2000. Timing the end-Triassic mass extinction: first on land, then in the sea? Geology 28, 39-42.

Pedersen, K.R., Lund, J.J., 1980. Palynology of the plant-bearing Rhaetian to Hettangian Kap Stewart Formation, Scoresby Sund, East Greenland. Review of Palaeobotany and Palynology 31, $1-69$.

Rainforth, E., 2003. Revision and re-evaluation of the early Jurassic dinosaurian ichnogenus Otozoum. Palaeontology 46, 803-838.

Ruckwied, K., Götz, A.E., Pálfy, J., Michalík, J., 2006. Palynomorph assemblages of Triassic/Jurassic boundary key sections of the NW Tethyan realm: evidence for climatic change. Volumina Jurassica 4, 297.

Schoene, B., Crowley, J.L., Condon, D.J., Schmitz, M.D., Bowring, S.A., 2006. Reassessing the uranium decay constants for geochronology using ID-TIMS U-Pb data. Geochimica et Cosmochimica Acta 70, 426-445.

Schuurman, W.M.L., 1977. Aspects of late Triassic palynology; 2, Palynology of the 'Gres et schiste a Avicula contorta' and 'Argiles de Levallois' (Rhaetian) of northeastern France and southern Luxemburg. Review of Palaeobotany and Palynology 23, 159-253.

Schuurman, W.M.L., 1979. Aspects of Late Triassic palynology.3. Palynology of latest Triassic and earliest Jurassic deposits of the northern limestone Alps in Austria and southern Germany, with special reference to a palynological characterization of the Rhaetian stage in Europe. Review of Palaeobotany and Palynology 27, 53-75.

Shubin, N.H., Olsen, P.E., Sues, H.-D., 1994. Early Jurassic small tetrapods from the McCoy Brook Formation of Nova Scotia, Canada. In: Fraser, N.C., Sues, H.D. (Eds.), In the Shadow of Dinosaurs: Early Mesozoic Tetrapods. Cambridge University Press, Cambridge, pp. 242-250.

Szajna, M.J., Silvestri, S.M., 1996. A new occurrence of the ichnogenus Brachychirotherium: implications for the TriassicJurassic mass extinction event. Museum of Northern Arizona Bulletin 60, 275-283.

Tanner, L.H., Kyte, F.T., 2005. Anomalous iridium enrichment in sediments at the Triassic-Jurassic boundary, Blomidon Formation, Fundy basin, Canada. Earth and Planetary Science Letters 240, 634-641.
Tanner, L.H., Lucas, S.G., Chapman, M.G., 2004. Assessing the record and causes of late Triassic extinctions. Earth-Science Reviews 65, 103-139.

Thulborn, T., 2003. Comment on "Ascent of dinosaurs linked to an iridium anomaly at the Triassic-Jurassic boundary". Science 301, 169 b.

Traverse, A., 1988a. Plant evolution dances to a different beat. Historical Biology 1, 277-301.

Traverse, A., 1988b. Paleoplaynology. Unwin Hyman, Boston. 600 pp.

Van Veen, P.M., 1995. Time calibration of Triassic/Jurassic microfloral turnover, eastern North America — comment. Tectonophysics 245, 93-95.

Ward, P.D., Haggart, J.W., Carter, E.S., Wilbur, D., Tipper, H.W., Evans, T., 2001. Sudden productivity collapse associated with the TriassicJurassic boundary mass extinction. Science 292, 1148-1151.

Ward, P.D, Garrison, G.H., Haggart, J.W., Kring, D.A., Beattie, M.J., 2004. Isotopic evidence bearing on Late Triassic extinction events, Queen Charlotte Islands, British Columbia, and implications for the duration and the cause of the Triassic/Jurassic mass extinction. Earth and Planetary Science Letters 224, 589-600.

Warrington, G.H., 1974. Studies in the palynological biostratigraphy of the Bristish Trias, 1, reference sections in West Lancashire and North Somerset. Review of Palaeobotany and Palynology 17, 133-147.

Warrington, G., 2005. The Triassic-Jurassic boundary - a review. In L'Hettangian à Hettange de la science au patrimoine, Réserve Naturelle Hettange-Grande. Moselle 11-14.

Warrington, G., Cope, J.C.W., Ivimey-Cook, H.C., 1994. St. Audrie's Bay, Somerset, England: a candidate global stratotype section and point for the base of the Jurassic System. Geological Magazine 131, 191-200.

Warrington, G., Ivimey-Cook, H.C., Edwards, R.A., Whittaker, A., 1995. The late Triassic-Early Jurassic succession at Selworthy, west Somerset, England. Proceedings Ussher Society, vol. 8, pp. 426-432.

Weems, R.E., 1992. The terminal Triassic catastrophic extinction eventh in perspective: a review of Carboniferous through Early Jurassic terrestrial vertebrate extinction patterns. Palaeogeography, Palaeoclimatology, Palaeoecology 94, 1-29.

Whiteside, J.H., Olsen, P.E., Sambrotto, R.N., 2003. Negative $\delta 13$ carbon isotope anomaly in continental strata at the TriassicJurassic boundary in eastern North America (Newark basin, Pennsylvania, USA). Abstracts with Programs - Geological Society of America 34 (7), 160.

Whiteside, J.H., Olsen, P.E., Sambrotto, R.N., Cornet, B., 2004. Negative $\delta^{13} \mathrm{C}$ anomaly in the Pangean arid tropics. 32nd International Geological Congress, pp. 253-256.

Whiteside, J.H., Olsen, P.E., Kent, D.V., Fowell, S.J., Et-Touhami, M., 2007. Synchrony between the Central Atlantic magmatic province and the Triassic-Jurassic mass-extinction event? Palaeogeography, Palaeoclimatology, Palaeoecology 244, 345-367.

Williford, K.H., Ward, P.D., Garrison, G.H., Buick, R., 2007. An extended organic carbon-isotope record across the TriassicJurassic boundary in the Queen Charlotte Islands, British Columbia, Canada. Palaeogeography, Palaeoclimatology, Palaeoecology 244, 290-296.

Yang, Z., Moreau, M-G., Bucher, H., Dommergues, J-L., Trouiller, A., 1996. Hettangian and Sinemurian magnetostratigraphy from Paris basin. Journal of Geophysical Research B101, 8025-8042. 